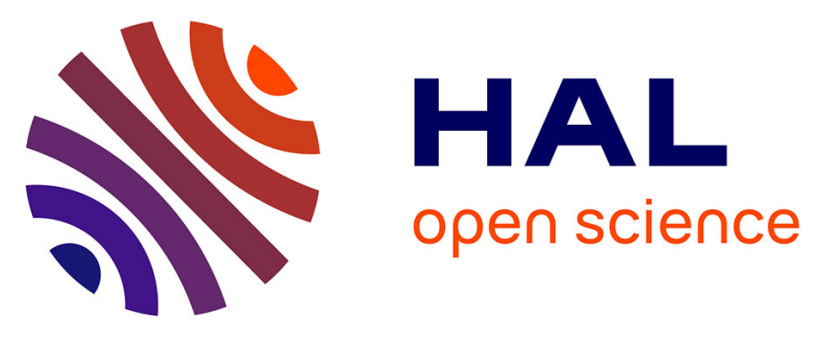

\title{
Mammary epithelial cell hierarchy in the dairy cow throughout lactation
}

\author{
Marie-Hélène Perruchot, Magdalena Arevalo Turrubiarte, Florence Dufreneix, \\ Laurence Finot, Vanessa Lollivier, Eric Chanat, Frederique Mayeur, Frederic
}

Dessauge

\section{To cite this version:}

Marie-Hélène Perruchot, Magdalena Arevalo Turrubiarte, Florence Dufreneix, Laurence Finot, Vanessa Lollivier, et al.. Mammary epithelial cell hierarchy in the dairy cow throughout lactation. Stem Cells and Development, 2016, 25 (19), pp.1407-1418. 10.1089/scd.2016.0098 . hal-02636214

\section{HAL Id: hal-02636214 \\ https://hal.inrae.fr/hal-02636214}

Submitted on 27 May 2020

HAL is a multi-disciplinary open access archive for the deposit and dissemination of scientific research documents, whether they are published or not. The documents may come from teaching and research institutions in France or abroad, or from public or private research centers.
L'archive ouverte pluridisciplinaire HAL, est destinée au dépôt et à la diffusion de documents scientifiques de niveau recherche, publiés ou non, émanant des établissements d'enseignement et de recherche français ou étrangers, des laboratoires publics ou privés.

\section{다(1)(2)}

Distributed under a Creative Commons Attribution - ShareAlikel 4.0 International 


\section{Mammary epithelial cell hierarchy in the dairy cow throughout lactation}

Marie-Hélène Perruchot ${ }^{1}$; Magdalena Arévalo-Turrubiarte ${ }^{1}$; Florence Dufreneix ${ }^{1}$; Laurence

Finot $^{1}$; Vanessa Lollivier ${ }^{1}$; Eric Chanat $^{1}$; Frédérique Mayeur ${ }^{1}$ and Frédéric Dessauge ${ }^{1 *}$

${ }^{1}$ PEGASE, Agrocampus Ouest, INRA, 35590 Saint-Gilles, France

* Corresponding author: Frédéric Dessauge, INRA, UMR1348 Pegase, Domaine de la Prise, 35590 Saint-Gilles, France. Tel: +33 2234850 97; Fax: +33 22348 50 80; E-mail: frederic.dessauge@inra.fr 


\begin{abstract}
The plasticity of the mammary gland relies on adult mammary stem cells (MaSC) and their progenitors, which give rise to various populations of mammary epithelial cells (MEC). To face global challenges, an in-depth characterization of milk-producing animal mammary gland plasticity is required, to select more sustainable and robust dairy cows. The identification and characterization of MaSC and their progenitors will also provide innovative tools in veterinary/human medicine regarding mammary tissue damage (carcinogenesis, bacterial infections). This study aimed to determine the dynamics of mammary cell populations throughout a lactation cycle. Using mammary biopsies from primiparous lactating dairy cows at 30, 90, 150 and 250 days of lactation, we phenotyped cell populations by flow cytometry. To investigate cell lineages, we used specific cell-surface markers including CD49f, CD24, EpCAM and CD10. Two cell populations linked to milk production were identified: $\mathrm{CD}_{4} 9_{\mathrm{f}}^{+} / \mathrm{EpCAM}^{-}\left(\mathrm{y}=0.88 \mathrm{x}+4.42, \mathrm{R}^{2}=0.36, p<0.05\right)$ and $\mathrm{CD}_{4} 9_{\mathrm{f}}^{-} / \operatorname{EpCAM}^{-}(\mathrm{y}=-$ $\left.1.15 \mathrm{x}+92.44, \mathrm{R}^{2}=0.51, p<0.05\right)$ cells. Combining immunostaining analysis, flow cytometry, daily milk production data and statistical approaches, we defined a stem cell population $\left(\mathrm{CD} 24^{+} / \mathrm{CD}_{4} 9_{\mathrm{f}}^{+}\right)$and four progenitor cell populations that include bi-potent luminal progenitors $\left(\mathrm{CD} 24^{-} / \mathrm{CD} 49_{\mathrm{f}}^{+}\right)$, lumino-alveolar progenitors $\left(\mathrm{CD} 24^{-} / \mathrm{EpCAM}^{+}\right)$, myoepithelial progenitors $\left(\mathrm{CD} 24^{+} / \mathrm{CD} 10^{-}\right)$and lumino-ductal progenitors $\left(\mathrm{CD} 49_{\mathrm{f}}^{-} / \mathrm{EpCAM}^{+}\right)$.

Interestingly, we found that the bi-potent luminal progenitors $\left(\mathrm{CD} 24^{-} / \mathrm{CD} 49_{\mathrm{f}}^{+}\right)$decreased significantly $(p<0.05)$ during lactation. This study provides the first results of mammary cells lineage, allowing insight into mammary cell plasticity during lactation.
\end{abstract}




\section{INTRODUCTION}

Milk yield (MY), and therefore the sustainability of livestock, is determined by breeding strategies and is finely regulated by cellular mechanisms determining the number and the activity of secretory cells [1] within the mammary gland. The mammary epithelium is composed of two cell layers: a luminal layer, lining the lumen of ducts and alveoli, and an external basal myoepithelial layer [2]. The stroma compartment that surrounds this epithelium is composed of several other cell types (adipocytes, fibroblasts and immune cells) that are responsible for mammary plasticity and homeostasis. During lactation in the dairy cow, the mammary tissue undergoes extensive morphological and functional remodeling, linked to cellular and architectural changes [3]. During early lactation, the rate of proliferating mammary cells overtakes the rate of apoptosis, thereby increasing the number of mammary cells. The decline in MY during late lactation is due to loss of mammary cells (apoptosis) and remodeling of mammary tissue. This results in alveolar regression during involution [4]. To date, our understanding of the phenotypic differentiation of mammary epithelial cells is limited. Current knowledge in mice and humans indicates the existence of stem cell and/or bipotent stem/progenitor cell populations that give rise to mature/differentiated cells [5]. The presence of mammary stem cells (MaSC) and their progenitors in the bovine mammary gland has been recently shown [6]. Since they play a crucial role in cell proliferation and tissue regeneration, the characterization of bovine MaSCs is needed, in order to improve dairy cow productivity and mammary gland health, as well as to expand the lifespan of cows. In addition, the bovine mammary gland represents an excellent alternative model for biomedical research to investigate the role of MaSC in mammary function and carcinogenesis [7].

Evidence for the existence of MaSCs has been primarily derived from transplantation experiments with murine mammary tissues. These studies revealed that ductal architecture could be regenerated in vivo when isolated parenchymal segments were transplanted into 
cleared mammary fat pads [8-10]. Furthermore, it was shown that epithelial cells isolated from virgin, pubertal, gestational, and lactating glands could all repopulate cleared fat pads [9]. As such a variety of parenchymal structures can regenerate a complete parenchymal framework, it is likely that progenitor or stem cells are present throughout the mammary epithelium. To date, MaSC studies in ruminants have been very sparse. Recently, Baratta et al. (2015) investigated different epithelial cell subpopulations in milk cells by flow cytometry [11]. They found an increase in $\mathrm{CD} 49_{\mathrm{f}}^{+}$cells and cytokeratin $14 / 18$ cells at the end of lactation in dairy cows. In 2002, Ellis and Capuco were the first to provide data on the proliferation rate of mammary epithelial cells (MEC), using histological analysis of mammary gland explants from heifers, which were injected with BrdU before euthanasia [6]. They identified different staining intensities in mammary epithelial cell populations, and proposed that the lightly stained cells were the primary proliferative cell population. In 2010, Martignani et al. showed that a putative bovine mammary stem cell population was able to regenerate and maintain a complete mammary gland structure [12]. They hypothesized that these putative MaSC can give rise either to luminal (cytokeratin 18 positive) or myoepithelial (cytokeratin 14 positive) cells under specific cell culture conditions. To our knowledge, no studies have been performed on the lineage, hierarchy and proportion of mammary cell populations throughout a lactation cycle.

Flow cytometry with specific cell-surface markers is a sensitive approach to lineage and quantify cell populations and subpopulations in the mammary gland [7]. The expression of cluster of differentiation (CD) molecules, such as heat stable antigen (CD24) and integrin alpha-6 (CD49 $)$ have been widely used to identify epithelial cells in the mammary gland $[13,14]$. Recently, four populations have been found in the developing mammary gland (at puberty) by expression of CD24 and CD49f. Cell sorting experiments allowed the characterization of putative stem cells $\left(\mathrm{CD} 24^{\mathrm{Med}} \mathrm{CD} 49_{\mathrm{f}}^{\text {Pos }}\right)$, putative progenitor cells 
$\left(\mathrm{CD} 24^{\mathrm{High}} \mathrm{CD} 49_{\mathrm{f}}^{\mathrm{Neg}}\right)$, and basal $\left(\mathrm{CD} 24^{\mathrm{Neg}} \mathrm{CD} 49_{\mathrm{f}}^{\mathrm{Pos}}\right)$ and luminal $\left(\mathrm{CD} 24^{\mathrm{Med}} \mathrm{CD} 49_{\mathrm{f}}^{\mathrm{Neg}}\right)$

subpopulations[15]. In the human mammary gland, the combination of the cell-surface markers EpCAM (Epithelial Cell Adhesion Molecule) and CD49 $9_{\mathrm{f}}$ has served to identify basal cell populations $[16,17]$. In lactating goats, EpCAM has been found by immunostaining in luminal populations of alveoli, and seems to be related to cell proliferation [18]. Moreover, cell populations expressing EpCAM and $\mathrm{CD} 49_{\mathrm{f}}$ represent a source of mammary progenitors with stem cell characteristics, due to their ability to form mammospheres [19-21]. To characterize myoepithelial cells, the neutral endopeptidase CD10, also called Common Acute Lymphoblastic Leukemia Antigen (CALLA), has been identified at the apical surface of myoepithelial cells during cell contraction in the mammary gland [22,23]. In the bovine mammary gland, CD10 has also been shown to be a relevant marker of myoepithelial cell differentiation in prepubertal bovine mammary gland [24].

The present study aims to determine the cellular hierarchy throughout a lactation cycle, in order to understand the involvement of the various cellular populations in bovine mammary gland plasticity and milk production. Toward this aim, we used flow cytometry to identify cellular populations using the cell-surface markers CD49,, CD24, EpCAM and CD10 in mammary explant sampled from lactating dairy cows at 30, 90, 150 and 250 days of lactation. The identification of cell populations allowed us to highlighted MEC plasticity during lactating periods. 


\section{MATERIALS \& METHODS}

All animal procedures were discussed and approved by the National Ethics Committee for Animal Experiments (File number: 00943.02), in compliance with French regulations (Decree No. 2001-464, May 29, 2001).

\section{Animals and Experimental Design}

The five primiparous Holstein cows used in this study were raised at the Méjusseaume INRARennes (France) experimental barn. The cows were collectively housed and fed in barns during the winter and in fields during the summer. They were milked twice daily during the entire experimental period.

\section{Milk production recording and milk composition analysis}

The MY was recorded daily for fifty-two weeks. Milk samples were collected weekly for somatic cell counting (SCC) and milk composition analysis. Milk protein and fat contents were determined by an independent laboratory using an infrared method (Lillab, Chateaugiron, France).

\section{Mammary tissue sampling}

Mammary tissue samples were collected by biopsy at days 30 (B1), 90 (B2), 150 (B3) and 250 (B4) of lactation (adapted from the method of Farr et al. [25]) from the left and the right halves of the udder. Biopsies were taken approximately halfway between the base of the teat and the dorsal body wall in a region containing a large amount of secretory tissue. Each biopsy was divided into three parts. The first part was cut into small explants $\left(1 \mathrm{~mm}^{3}\right)$ and samples were stored in 90\% fetal bovine serum (FBS, Gibco, 10270-106)/ 10\% dimethylysulfoxide (DMSO) at $-150^{\circ} \mathrm{C}$ for tissue digestion and cell isolation. The second part 
was immediately frozen in liquid nitrogen and stored at $-80{ }^{\circ} \mathrm{C}$ until RNA extraction was performed. The last part was washed in phosphate-buffered saline (PBS) before fixation for histological analysis (see below). DMSO and PBS were from Sigma-Aldrich (Saint-Quentin Fallavier, http://www.sigmaaldrich.com/france). FBS was purchased from Invitrogen (Gibco Invitrogen Saint Aubin, France, http://www.invitrogen.com).

\section{Mammary biopsy digestion and single cell suspension}

Tissue explants were thawed and incubated for three hours at $37^{\circ} \mathrm{C}$ in a digestion medium containing Dulbecco's modified Eagle medium nutrient mixture F-12 (DMEM-F12, Gibco, 31331-028), 5\% FBS, $5 \mu \mathrm{g} / \mathrm{mL}$ insulin (Sigma, 15523), $1 \mu \mathrm{g} / \mathrm{mL}$ hydrocortisone (Sigma, H0888), $7000 \mathrm{U} / \mathrm{mL}$ collagenase type II (Worthington 54N15271) and $2000 \mathrm{U} / \mathrm{mL}$ hyaluronidase (Sigma, H3506-G1). After centrifugation at $500 \mathrm{x}$ g for 5 minutes at $4^{\circ} \mathrm{C}, 2$ $\mathrm{mL}$ of trypsin-ethylene-diamine-tetracetic acid (EDTA, Sigma, T4049-100ML) was added to the pellet to complete the dissociation process. After centrifugation, the pellet, composed of cells and remaining tissue, was drained through a $70 \mu \mathrm{m}$ filter (Miltenyi Biotec, http://www.miltenyibiotec.com/en/) and washed with Hank's balanced salt solution (HBSS), $5 \%$ FBS, to obtain a single cell suspension. Cells were then processed for flow cytometry phenotyping (see below). Collagenase was purchased from Serlabo (http://www.serlabo.fr/index.php).

\section{Histological analysis}

Mammary tissue samples were fixed in $4 \%$ paraformaldehyde (pH 7.4) (Sigma Aldrich, P6118) for $2 \mathrm{~h}$ and paraffin-embedded (Sigma Aldrich, 327204) using standard protocols provided by the H2P2 platform (University of Rennes 1, France). Tissue sections ( $5 \mu \mathrm{m}$ 
thickness) were mounted on SuperFrostPlus slides (ThermoScientific, 4951PLUS4, Paris, France, http://www.thermoscientific.com/en/home.html), deparaffinized with 3 different xylene baths and rehydrated in successive graded ethanol-water baths (100\% ethanol, $90 \%$ ethanol, $70 \%$ ethanol and distilled water). After rehydration, the tissue sections were either stained with hematoxylin and eosin or processed for immunohistochemical labeling. After hematoxylin/eosin staining and drying, the slides were scanned using NanoZoomer Digital Pathology technology (Hamamatsu, Kitsa, Sweden) with automatic detection of the entire tissue section.

\section{Immunological staining procedure}

Immunohistochemical labeling was performed using slides bearing three tissue sections. Two tissue sections were processed for each primary antibody, while the third section was used as a negative control. Following rehydration, tissue sections were pre-incubated for $1 \mathrm{~h}$ in $0.2 \%$ Triton-X100, $1 \%$ normal goat serum (NGS) in Tris-buffered saline (TBS) (1\% TBS-NGS) and incubated overnight at $4{ }^{\circ} \mathrm{C}$ with either anti-CD10-PE, anti-CD49f-PE, anti-EpCAMFITC, anti-CD24-PE or $\alpha$ SMA antibodies, all diluted at 1:200. Negative control (Isotypes) tissue sections were incubated in a drop of $1 \%$ TBS-NGS. Slides were rinsed with TBS and incubated with the relevant isotype control (1:300 dilution) for $1 \mathrm{~h}$ at room temperature.

Slides were washed in TBS, treated with Hochst 33258 dye (Sigma Aldrich, Lyon, France) and mounted with Vectashield mounting medium (H-1000, Vector Laboratories, Burlingame, USA). Tissue sections were observed by fluorescence microscopy using an Eclipse E400 Nikon microscope (Nikon France, Le Pallet, France), using both $568 \mathrm{~nm}$ and $350 \mathrm{~nm}$ wavelength absorption/excitation. 


\section{RT-qPCR Procedure}

Total RNA was extracted from tissue samples after grinding them in liquid nitrogen with a mortar and pestle using Trizol (Invitrogen, Paris, France). Briefly, tissue powder was homogenized in $1 \mathrm{~mL}$ of Trizol reagent, incubated for $5 \mathrm{~min}$ at room temperature and supplemented with $200 \mu \mathrm{L}$ chloroform (Sigma Aldrich). The mixture was centrifuged at $12000 \mathrm{x}$ g for $15 \mathrm{~min}$ at $4{ }^{\circ} \mathrm{C}$ and the upper aqueous phase, which contains the total RNA, was recovered and mixed with $500 \mu \mathrm{L}$ of isopropyl alcohol to precipitate the RNA. Total RNA was extracted using the RNeasy Mini kit according to the manufacturer's instructions (Qiagen, 74014). Total RNA concentration and the $260 / 280 \mathrm{~nm}$ and $260 / 230 \mathrm{~nm}$ absorbance ratios were measured on a NanoDrop ND-1000 spectrophotometer (NanoDrop Technologies, Wilmington, DE, USA). RNA quality was then determined on an Agilent 2100 Bioanalyzer (Agilent Technologies, Massy, France) by RNA profile and RNA integrity, measured using Agilent 2100 Expert Software, version B.02 (Agilent Technologies, http://www.agilent.com/home). Subsequently, total RNA (1 $\mu \mathrm{g})$ was reverse-transcribed using the Vilo SuperScript kit according to the manufacturer's recommendations (Invitrogen, 11754-050). The cDNA was diluted 1:50 prior to use in quantitative real time polymerase chain reaction (RT-qPCR). Following reverse transcription, RT-qPCR was run on a StepOne Plus system (Applied Biosystems). Triplicate $12.5 \mu \mathrm{L}$ reactions were carried out in 96-well optical reaction plates (Applied Biosystems, http://www.agilent.com/home) using SYBR Green PCR master mix with $200 \mathrm{nM}$ of specific primer (Cytokeratin 19: Forward 5' GGCGGGCAACGAGAAGC 3', Reverse 5' CGAGAATCTGGTCCCGCAG 3') and $2.5 \mu \mathrm{L}$ of diluted cDNA.

The amplification program consisted of an initial denaturation step at $95^{\circ} \mathrm{C}$ for $10 \mathrm{~min}$ followed by 40 cycles of denaturation at $95^{\circ} \mathrm{C}$ for $10 \mathrm{sec}$ and combined primer-annealingextension at $60^{\circ} \mathrm{C}$ for $1 \mathrm{~min}$, during which fluorescence was measured. A melting curve was 
produced after completion of the thermal PCR program to check for the presence of a genespecific peak and the absence of a primer dimer. Raw cycle threshold $(\mathrm{Ct})$ values obtained from raw StepOne Software version 2.3 (Applied Biosystems) were transformed into quantities using the comparative Ct method [26] and specific efficiencies. Ribosomal Protein Large P0 (RPLP0: Forward 5' CAACCCTGAAGTGCTTGACAT 3', Reverse 5' AGGAGATGGATCAGCCA 3') was used as the endogenous control gene. Results at days 90,150 and 250 are expressed as percent of the tissue content at day 30.

\section{Flow cytometry analysis}

Cells obtained from mammary biopsy digestions were prepared for flow cytometry analysis with MACS buffer (autoMACS ${ }^{\text {TM }}$ with $2 \%$ bovine serum albumin, Miltenyi Biotec, France, http://www.miltenyibiotec.com). Cells were dispensed at 500000 cells in each tube. Cells were incubated in the dark at $4^{\circ} \mathrm{C}$ for 30 min with either one or a mixture of the following antibodies (see also Table 1): fluorescein isothiocyanate (FITC) anti-rat IgG1 CD49f ( $\alpha 6$ integrin), allophycocyanine (APC) anti-rat IgG2bк CD24 (clone HAS), Vioblue ${ }^{\circledR}$ anti-mouse IgG1 CD326 (EpCam) (Miltenyi Biotec) and anti-mouse IgG1 PE-VIO700 CD10 (CALLA) (Miltenyi Biotec). Isotype controls were performed for each antibody to set the specific fluorescence, eliminating non-specific background (Table 1). After labeling, cells were centrifuged at $400 \mathrm{x}$ g and re-suspended in $0.3 \mathrm{~mL}$ of MACS buffer. Multi-staining of the four antibodies was performed to determine specific populations. Propidium iodide (PI) was used to identify the live cells. Acquisition of the PI-stained population was gated to forwardscattered light (FSC) and side-scattered light (SSC) to exclude dead cells and delineate cell granularity and size, as well as doublets, by adjustments in height and photomultiplicator voltage. Flow cytometry analysis was performed on a data set of 30000 events (single cells) using a MACSQuant ${ }^{\circledR}$ Analyzer10 (Miltenyi Biotec) and data were analyzed using 
MACSQuantify analysis software (Miltenyi Biotec). Results were expressed in percentages (dot plot analysis).

\section{Statistical analysis}

Each experimental condition was repeated three times. Milk composition, flow cytometry and qPCR data were subjected to analysis of variance (one-way ANOVA) using the following model: $\mathrm{y}_{\mathrm{ij}}=\mu+$ time $_{\mathrm{i}}+\varepsilon_{\mathrm{ij}}(\mathrm{y}=$ flow cytometry data or qPCR data; $\mu=$ mean; $\mathrm{i}=$ time of biopsies and $\varepsilon=$ residuals). Post-hoc Tukey pairwise comparisons were used. Differences were considered significant at $p<0.05$. All statistical analyses were performed using $\mathrm{R}$ software (the $\mathrm{R}$ foundation). 


\section{RESULTS}

\section{Milk yield of primiparous lactating dairy cows}

Daily MY was recorded for the five primiparous cows, from calving to the drying-out period. As expected, the MY was significantly different at each mammary gland biopsy timepoint of mammary biopsies (30, 90, 150 and 250 days) with $29.9 \mathrm{~kg} /$ day, $34.3 \mathrm{~kg} / \mathrm{day}, 32.9 \mathrm{~kg} / \mathrm{day}$ and $19 \mathrm{~kg} /$ day, respectively $(p<0.05)$ (Figure 1). The mean of daily MY described a classical lactation curve, with a peak of production at $\approx 60$ days post-calving. Analysis of milk composition data showed that fat and protein yields varied according to MY, as expected during lactation in primiparous dairy cows (Table 2). Furthermore, somatic cell count (SCC) values were less than $250 \times 10^{3}$ cells / $\mathrm{mL}$ throughout lactation, showing the cows and their mammary glands were healthy. This prerequisite was the first step to validate our experimental model.

\section{Mammary gland morphology and differentiation during lactation}

The second step to validate our experimental approach was to examine the morphology of the mammary gland tissue using eosin/hematoxylin staining of tissue sections at each biopsy timepoint (Figure 2). At 30 days of lactation, the mammary alveoli displayed small luminal spaces (Figure 2, left upper panel). At 90 days, distinct luminal spaces appeared, in agreement with the high secretory activity of the MEC at this time of the lactation cycle (Figure 2, right upper panel). In contrast, we noted the regression of the alveolar structure at 150 and 250 days of lactation, with stromal tissue increasing and taking the place of the mammary epithelium at the end of lactation (Figure 2, lower panels). In line with these observations, we observed that the level of cytokeratin 19 (CK19), estimated using RT-qPCR (Figure 3) varied significantly throughout lactation, with maximal expression at 150 days of lactation $(p<0.05)$. 


\section{In situ localization of cell-surface markers in mammary gland tissue}

To estimate the relevance of the four lineage markers used in the present study $\left(\mathrm{CD} 10, \mathrm{CD} 49_{\mathrm{f}}\right.$, CD24 and EpCAM), we characterized their expression in specific cell populations within mammary gland sections during lactation. DAPI staining allowed us to identify nuclei in the alveoli and stroma. Immunohistochemical labeling using antibodies against CD10 showed exclusive staining of cells surrounding the luminal MEC layer, corresponding to myoepithelial cells (Figure 4A, left panels). In line with this, alpha smooth muscle actin ( $\alpha$ SMA) counterstaining was observed in the myoepithelial cell layer around CD49 $9_{\mathrm{f}}$ positive cells (Figure 4A, right panels). CD49f was expressed and localized in cells located in the basal part of the lumen. Expression of CD24 and EpCAM was also examined in situ. CD24 was only detected in some of the cells located in the luminal MEC layer (Figure 4B, left panels). Higher magnification of CD24 staining confirmed the specific cell-surface staining and localization (Figure 4B, left panels, insets). With regard to EpCAM localization, we observed apical staining in some of the luminal MEC (Figure 4B, right panels).

\section{Gating strategy for flow cytometry data analysis}

To validate the multicolor panel of the four antibodies used in the present study, coupled with four different fluorochromes, we performed single cell staining with each antibody (Table 3) and Fluorescent Minor One. To develop this technique, essential to set up our multicolor assays, we used a manual compensation matrix based on the median fluorescence intensity procedure. We also ensured that only single living cells were analyzed, by eliminating cell aggregates and dead cells from our analysis. In order to eliminate aggregates, we performed doublet exclusion using FSC-H/A and SSC-H/A parameters. To discriminate between live cells and dead cells, we used PI staining. This technical strategy is essential to analyze each cell-surface marker in single living cells (Figure 5A). The strategy to analyze the expression 
of the three others cellular markers used in the present study within a stained population (here, the CD49f positive cells) is illustrated in Figure 5B. In our example, we gated on CD49fpositive cells to analyze co-immunostained populations: CD49f and EpCAM, CD49f and CD10, CD49f and CD24. This procedure was applied for each cell-surface marker (CD49f, CD10, CD24 and EpCAM).

\title{
Cell hierarchy and lineage in the bovine mammary gland during throughout lactation
}

\author{
After tissue dissociation and single cell isolation, we determined the proportion of each \\ putative cell type according to the expression of cell-surface markers at four stages of the \\ lactation cycle, namely 30, 90, 150 and 250 days of lactation. Flow cytometry dot-plots \\ depicting the main populations $\left(\mathrm{CD} 49_{\mathrm{f}}^{+}, \mathrm{CD} 24 / \mathrm{CD} 49_{\mathrm{f}}\right.$ and $\left.\mathrm{CD} 49_{\mathrm{f}} / \mathrm{EpCAM}\right)$ at 30 days, 90 \\ days, 150 days and 250 days of lactation were presented in Figure 6. First, we analyzed single \\ staining with CD24, CD10, EpCAM and CD49f cell-surface markers (Table 3). We observed \\ that the predominant cell population expressed CD49f. Interestingly, the proportion of CD49f- \\ positive cells significantly decreased over the lactation cycle (B1: 47\% vs. B4: 28.8\%, $p$ \\ $<0.05$, data not shown). The proportions of the other single-stained cell populations were \\ lower $(<7 \%)$ and their expression did not vary during lactation (data not shown).
}

Next, we defined double-stained cell populations using combinations of CD10, CD49f, CD24 and EpCAM markers. The different marker combinations were determined in accordance with their specific localization, as observed by immunochemistry and reported in the literature for other lactating species (Table 4). First, we showed that the proportion of CD24 $4^{+}$CD $49_{\mathrm{f}}^{+}$cells did not significantly evolve throughout the lactation cycle. Concerning the putative progenitor populations, we found that $\mathrm{CD} 24^{-} / \mathrm{CD} 49_{\mathrm{f}}^{+}$cells represented the majority of the cells among the putative progenitors. Of note, the proportion of this cell population significantly decreased during lactation, from $38.2 \%$ (B1) to $23.8 \%$ (B4) $(p<0.05)$. On the other hand, the proportions 
of the other putative progenitors were very low $(0.7 \%$ to $5.1 \%)$ and their expression did not vary significantly during lactation. Next, we focused on the mature (differentiated) cell populations. The cell populations which did not express EpCAM and in which CD49 $9_{\mathrm{f}}$ was either present or absent $\left(\mathrm{CD} 49_{\mathrm{f}}^{+} / \mathrm{EpCAM}^{-}\right.$and $\left.\mathrm{CD} 49_{\mathrm{f}}^{-} / \mathrm{EpCAM}^{-}\right)$were the most abundant putative mature cells. Interestingly, the variations in both populations over the lactation period were in opposite directions. Indeed, the $\mathrm{CD}_{49 \mathrm{f}^{+}} / \mathrm{EpCAM}^{-}$cells significantly decreased while the $\mathrm{CD}_{49} \mathrm{f}^{-}$EpCAM${ }^{-}$cells increased from $38 \%$ (B1) to $21.5 \%$ (B4) and from $55 \%$ (B1) to $68.5 \%$ (B4), respectively. The proportion of the third population of putative mature cells, i.e., $\mathrm{CD} 49_{\mathrm{f}}^{+} / \mathrm{CD} 10^{+}$cells did not significantly vary between 30 and 250 days of lactation, and remained low (from $1.7 \%$ to $3.4 \%$ ).

\section{Correlation between putative mature cell proportion and milk yield}

Statistical analysis showed a positive correlation between the proportions of CD49 $9_{\mathrm{f}}$ positive cells and the MY $\left(\mathrm{R}^{2}=0.39, p<0.05\right)$, as the number of $\mathrm{CD} 49_{\mathrm{f}}$ positive cells increased as the level of milk production increased (Figure 7A). In contrast, we observed opposite changes in the proportion of $\mathrm{CD}_{4} 9_{\mathrm{f}}{ }^{-} / \mathrm{EpCAM}^{-}$cells and the proportion of $\mathrm{CD} 49_{\mathrm{f}}{ }^{+} / \mathrm{EpCAM}^{-}$cells in relation to MY (Figure 7B and 7C). Indeed, the correlation between CD49 ${ }_{\mathrm{f}}^{-} / \mathrm{EpCAM}^{-}$cells and milk production was negative $\left(\mathrm{R}^{2}=0.51, p<0.05\right.$, Figure $\left.6 \mathrm{~B}\right)$, whereas the proportion of $\mathrm{CD} 49_{\mathrm{f}}{ }^{+} / \mathrm{EpCAM}^{-}$cells positively correlated with milk production $\left(\mathrm{R}^{2}=0.35, p<0.05\right.$, Figure 7C). 


\section{DISCUSSION}

During the development of the mammary gland (mammogenesis) and lactation (galactopoiesis) in dairy cows, each cell population has a specific feature involved in mammary gland plasticity. Like most glandular tissue, the adult mammary gland is composed of many cell types that interact to shape the organ and make it functional. In this study, we specifically focused on epithelial-like, myoepithelial and progenitor/stem cells implicated in mammary gland plasticity. Flow cytometry is a suitable method to analyze and to discriminate between single cell phenotypes on precious and small samples such as mammary gland biopsies. We used this method to analyze and to identify the lineage of cell populations based on the expression of cell-surface markers commonly used in the mammary gland field:

CD49f, CD24, CD10 and EpCAM. The prerequisites for our study were to ensure that mammary explant samples were representative of a lactating mammary gland. Using five primiparous dairy cows, we first monitored their zootechnical data in order to ensure their MY responses and the quality of the milk composition. A classical lactation curve is defined by a peak in milk production between 30 and 90 days of lactation, followed by a decrease in milk production. To validate the mammary gland samples prior to the phenotypic characterization of mammary cells, we observed the morphology of the tissue obtained by biopsy and analyzed the expression of the $C K 19$ gene (a conventional marker of mature alveolar cells $[27,28])$. As expected, we observed an increase in the surface of luminal spaces in alveoli at 90 days of lactation, followed by a decline, which correlated with the decline in MY. These key events validated that the mammary biopsies represented well the four chosen stages of lactation.

In this study, we demonstrated that cell populations expressing EpCAM and CD49 $9_{\mathrm{f}}$ cell-surface markers varied significantly and inversely during lactation from 30 days to 250 days of lactation. Indeed, 30 days after the beginning of lactation, the proportion of CD49 ${ }_{\mathrm{f}}^{+}$/ 
$\mathrm{EpCAM}^{-}$cells reached their maximal expression level (38\%) while the proportion of CD49- ${ }_{\mathrm{f}}^{-} /$ $\mathrm{EpCAM}^{-}$cells started at their minimal expression level (55\%). We also showed that these relative proportions were reversed in late lactation, with $21 \% \mathrm{CD} 9_{\mathrm{f}}^{+} / \mathrm{EpCAM}^{-}$cells and 68.5\% $\mathrm{CD}^{-} 9_{\mathrm{f}}^{-} / \mathrm{EpCAM}^{-}$cells. Moreover, the statistical correlations established between $\mathrm{CD}_{4} 9_{\mathrm{f}}^{+} / \mathrm{EpCAM}^{-}$cells, $\mathrm{CD}_{4} 9_{\mathrm{f}}^{-} / \mathrm{EpCAM}^{-}$cells and MY demonstrated that these two cell populations are related to milk production. When milk production increased, the proportion of $\mathrm{CD}_{4} 9_{\mathrm{f}}^{+} / \mathrm{EpCAM}^{-}$cells increased, whereas the proportion of $\mathrm{CD}^{-} 9_{\mathrm{f}}^{-} / \mathrm{EpCAM}^{-}$cells decreased. Both $\mathrm{CD} 49_{\mathrm{f}}$ and EpCAM are cell-surface markers associated with cell adhesion, and are very often used to phenotype mammary gland cells and their degree of maturation. Altogether, these data and the literature strongly suggest that mammary alveolar cells that are involved in milk production (myoepithelial and lumino-alveolar cells) expressed CD49 $9_{\mathrm{f}}$, while epithelial cells present in the mammary ducts (lumino-ductal cells) did not express this marker. CD49f is also expressed mainly by bi-potent progenitors and basal/myoepithelial cells of the breast [29-31]. Additionally, it is well known that the loss of EpCAM is correlated to a decrease in progenitor activity [31]. Thus, we hypothesized that differentiated mature cells did not express the marker EpCAM. Considering these results and the literature, we hypothesize that $\mathrm{CD} 49_{\mathrm{f}}$ and $\mathrm{EpCAM}$ are suitable markers to discriminate between mature luminal cells and their progenitors. In 2012, Rauner and Barash demonstrated that CD24 / $\mathrm{CD} 49_{\mathrm{f}}^{+}$cells are bi-potent progenitor cells that give rise to luminal progenitors and then differentiate into luminal cells. In human breast and mouse mammary gland, CD24- ${ }^{-} \mathrm{CD}_{4} 9_{\mathrm{f}}^{+}$ cells are also considered to be bi-potent progenitor cells. This has been established through in vivo transplantation and in vitro experiments [32,33]. In our study, the proportion of CD24- / $\mathrm{CD}_{4} 9_{\mathrm{f}}^{+}$cells significantly decreased during lactation (38\% in early lactation $v$ s. $23.8 \%$ in late lactation). In the lactating mammary gland, the self-renewal of MEC is constantly ensured by two mechanisms: cell proliferation and programmed cell death (apoptosis). Capuco et al. 
(2001) estimated that, in the lactating bovine mammary gland, the average rate of proliferation was about $0.3 \%$ per day and the average rate of apoptosis was about $0.56 \%$ per day, corresponding to a cell turnover of approximately 50\% during lactation [34]. Progenitor cells are the main actors in this biological process, as they both proliferate and give rise to differentiated cells involved in milk synthesis; these cells are then removed from the mammary epithelium by apoptosis. Thus, the high proportion of bi-potent progenitor cells found in early lactation is consistent with the literature.

In order to perform a complete lineage and cell hierarchy analysis in the bovine lactating mammary gland, we also focused on myoepithelial cells and their putative progenitors. A characteristic of myoepithelial cells is a dual phenotype of both smooth muscle (positive for $\alpha \mathrm{SMA}$ ) and epithelial cells [35]. Myoepithelial cells also express CD10 (neutral endopeptidase). Clarke et al. (1994) used CD10 as a myoepithelial marker to separate myoepithelial cells from luminal cells by immunomagnetic techniques [36]. In 2009, Ellis et al. showed that CD10 is a marker of myoepithelial cells within the mammary gland in heifers during mammogenesis. In our study, immunolocalization of CD10 in lactating mammary gland sections confirmed that CD10 was specifically expressed by myoepithelial cells [24]. Thus, we included CD10 in our flow cytometry panel, in order to thoroughly phenotype myoepithelial cells. Based on the presence of $\mathrm{CD} 49_{\mathrm{f}}$ at the surface of basal epithelial cells [37], we decided to combine CD49f and CD10 to analyze putative mature myoepithelial cells. Our results showed that the $\mathrm{CD} 49_{\mathrm{f}}^{+} / \mathrm{CD} 10^{+}$cell population, like the $\mathrm{CD} 10^{+}$population, were few and present without significant variation from B1 to B4. This stable proportion of putative myoepithelial cells proves that this population must be conserved during the entire lactation cycle. The same process has also been observed in skeletal muscle, in which the proportion of satellite cells is conserved for muscle homeostasis [38]. In murine mammary gland, the presence of mature and functional myoepithelial cells has been associated with the 
identification of myoepithelial progenitors and their expression of CD24 [5]. Despite very scarce literature about myoepithelial progenitor phenotypes, the transition from progenitors to differentiated cells occurs with different modifications, such as a switch in cell-surface markers. Hence, we hypothesized that the putative bovine myoepithelial progenitors were $\mathrm{CD} 10^{-} / \mathrm{CD} 24^{+}$. This hypothesis was supported by our immunostaining data, which demonstrated that $\mathrm{CD} 10^{+}$cells were mature myoepithelial cells only.

In many reports, the expression of CD24 is associated with a stem cell phenotype. In 2006, Shackleton et al. isolated a discrete subpopulation of mouse mammary cells on the basis of cell-surface markers (Lin-CD29hiCD24+). They showed that a single cell from this subpopulation, marked with a LacZ transgene, could reconstitute a complete mammary gland in vivo. The transplanted cell contributed to both the luminal and myoepithelial lineages and generated functional lobulo-alveolar units during pregnancy. The self-renewing capacity of these cells was demonstrated by serial transplantation of clonal outgrowths. Here, we found, by immunolocalization, that CD24 was expressed by some luminal cells within the mammary epithelium. Rauner and Barash (2012) also showed CD24 $4^{+}$cells in the luminal compartment of developing mammary gland sections in heifers. CD24 is also highly expressed in luminal progenitors in the breast $[39,40]$. Using the combination of the $\mathrm{CD} 49_{\mathrm{f}}$ and $\mathrm{CD} 24$ markers to sort primary MEC, they isolated $\mathrm{CD} 24^{+} / \mathrm{CD} 49_{\mathrm{f}}^{+}$cell populations that were able to form large mammospheres in vitro. They also showed that these cells had a high proliferation rate and were able to form organized colonies. These proliferative properties of undifferentiated cells define a stem cell phenotype, with the ability for multipotency and self-renewing. These features allowed defining the $\mathrm{CD} 24^{+} / \mathrm{CD} 49_{\mathrm{f}}^{+}$population as putative mammary stem cells. In our study, this population was present throughout lactation with a maximal proportion (3.3\%) observed at 90 days of lactation $(p=0.09)$. Therefore, the $\mathrm{CD} 24^{+} / \mathrm{CD} 49_{\mathrm{f}}^{+}$population could play this putative mammary stem cell role in bovine mammary gland. In conclusion, we 
hypothesized a stem cell population $\left(\mathrm{CD} 24^{+} / \mathrm{CD} 49_{\mathrm{f}}^{+}\right)$and four progenitor cell populations: bi-potent luminal progenitors $\left(\mathrm{CD} 24^{-} / \mathrm{CD} 49_{\mathrm{f}}^{+}\right)$, lumino-alveolar progenitors (CD24 / $\left.\mathrm{EpCAM}^{+}\right)$, myoepithelial progenitors $\left(\mathrm{CD} 24^{+} / \mathrm{CD} 10^{-}\right)$and lumino-ductal progenitors $\left(\mathrm{CD} 49_{\mathrm{f}}^{-}\right.$ / $\left.\operatorname{EpCAM}^{+}\right)$.

This study provides a dynamic view of the mammary cell populations based on common markers used in mammary gland cell lineage identification. Our next goal will be to carry out the same analyses on mammary glands at different physiological stages: before and after puberty, during gestation, as well as at the peak of lactation and at the drying-out stage. An analysis of functional proteins (cytokeratins, steroid receptors, aldehyde dehydrogenase activity) will be performed on sorted cells, isolated from the different populations described in this study and combined with mammosphere assays. In summary, this study not only contributes to a better understanding of the role of stem cells in the plasticity of the mammary gland, but also identifies new biomarkers for veterinary and human medicine.

\section{ACKNOWLEDGMENTS}

This research was co-supported by the French National Institute of Agricultural Science (INRA) and the INRA-PHASE department. 


\section{FIGURE LEGENDS}

Figure 1: Representative box plots of milk yield during the lactation cycle. Each box plot represents the mean (five dairy cows) of daily milk production $(\mathrm{kg} /$ day) prior to mammary gland biopsy at the indicated time point. The letters above the boxplots indicate statistically significant $(p<0.05)$ differences between each value and the value at each of the other three time points.

Figure 2: Organization of the mammary gland secretory tissue throughout lactation. Mammary tissue was collected by biopsy at 30, 90, 150 and 250 days of lactation and processed for hematoxylin/eosin histological staining. The stained tissue sections were scanned using a NanoZoomer (Hamamatsu). Scale bar $=500 \mu \mathrm{m}$.

Figure 3: Representative box plots of relative $C K 19$ gene expression throughout lactation. Each box plot represents the mean (five dairy cows) of CK19 expression at the indicated time point prior to mammary biopsy (RPLP0 was used as the reference gene). Results at days 90, 150 and 250 are expressed as percent of the tissue content at day 30. Different letters above the box plots indicate statistically significant $(p<0.05)$ differences between each value and the value at each of the other three time points.

Figure 4: In situ localization of cell-surface markers in lactating mammary gland tissue. (A) The left panels show the staining of myoepithelial cells using the iso-CD10 and CD10 antibodies. Nuclei were counterstained with DAPI. The right panels show basal part of the mammary lumen staining with iso-CD49 f $_{\mathrm{f}}$ (negative control) and $\mathrm{CD} 49_{\mathrm{f}}$ and myoepithelial cell staining with $\alpha$-SMA. (B) The left panels show the staining of some of the luminal cells using the anti-CD24 antibody compared with the negative control iso-CD24. The right panels show the negative control iso-EpCAM and the apical staining (white arrows) in some of the luminal 
MEC within the mammary acini using anti-EpCAM antibody. Nuclei were counterstained with DAPI. Scale bars $=50 \mu \mathrm{m}$.

Figure 5: Gating strategy used to analyze the stained cell populations by flow cytometry. (A) Gating strategy to set up the analysis of single living cells. Doublet exclusion using FSC-H/A and SSC-H/A parameters was performed. Propidium iodide allowed discrimination between living cells and dead cells. Each single staining with anti-CD49, , -CD10, -CD24 and -EpCAM antibodies was analyzed in living cells. (B) Illustration of the gating strategy used to analyze the multi-stained populations. Gated CD49f-positive cells were selected and then coimmunostained populations were analyzed: CD49 ${ }_{\mathrm{f}}$ and EpCAM, CD49 $9_{\mathrm{f}}$ and CD10, CD49 $\mathrm{f}$ and CD24.

Figure 6: Evolution of main MEC populations over the lactation. Flow cytometry dot-plots depicting the main populations at 30 days, 90 days, 150 days and 250 days of lactation. Upper panels highlighted CD49 $9_{\mathrm{f}}$-positive cells, middle panels: CD49 $9_{\mathrm{f}}$ CD24 populations and lower panels: CD49f / EpCAM populations.

Figure 7: Analysis of the correlation between the proportions of various cell populations and milk yield. (A) Correlation between the proportion of CD49 $9_{\mathrm{f}}$-positive cells and milk yield $\left(\mathrm{MY}, \mathrm{R}^{2}=0.39, p<0.05\right)$. (B) Correlation between the proportion of $\mathrm{CD}_{4} 9_{\mathrm{f}}^{-} / \mathrm{EpCAM}^{-}$cells and MY $\left(\mathrm{R}^{2}=0.51, p<0.05\right)$. (C) Correlation between the proportion of $\mathrm{CD}_{4} 9_{\mathrm{f}}^{+} / \mathrm{EpCAM}^{-}$ cells and MY $\left(\mathrm{R}^{2}=0.35, p<0.05\right)$. 


\section{TABLES}

Table 1: List of antibodies used in flow cytometry analysis and immunohistology.

Table 2: Milk yield, fat and protein contents and somatic cell count during lactation. The milk of five primiparous lactating cows was collected throughout lactation. The MY was recorded daily over 52 weeks. Milk samples were collected weekly for somatic cell counting (SCC) and to determine the milk fat and protein composition. The data are expressed as the mean values ( \pm SEM) at 30 (biopsy 1: B1), 90 (B2), 150 (B3) and 250 (B4) days of lactation. Different letters indicate statistically significant $(p<0.05)$ differences between each value and the value at each of the other three time points.

Table 3: Flow cytometry analysis of isolated cells dissociated from mammary biopsies using single staining. Mammary biopsies were collected at 30 (biopsy 1: B1), 90 (B2), 150 (B3) and 250 (B4) days of lactation. After tissue digestion and cell dissociation, single cell suspensions were phenotyped using anti-CD24, -EpCAM, -CD10 and -CD49f antibodies. Each data point corresponds to the mean $( \pm$ SEM) of fluorescence for each single staining. Different letters indicate statistically significant $(p<0.05)$ differences between each value and the values at each of the other three time points.

Table 4: Cell hierarchy and lineages in the bovine mammary gland throughout a lactation period. Mammary biopsies were collected at 30 (biopsy 1: B1), 90 (B2), 150 (B3) and 250 (B4) days of lactation. After tissue digestion, cell dissociation and single cell isolation, the proportion of each cell type was determined at each stage of lactation according to the expression of cell-surface markers. The proportions of double-stained cell populations, using EpCAM, CD49f, CD24 and CD10 markers, are presented as the mean of fluorescence $( \pm$ SEM). Different letters indicate statistically significant $(p<0.05)$ differences between each value and the values at each of the other three time points. 


\section{AUTHOR DISCLOSURE STATEMENT}

Study conception and design: Marie-Hélène Perruchot and Frédéric Dessauge. Acquisition of data: Florence Dufreneix, Laurence Finot, Frédérique Mayeur and Magdalena Arévalo-

Turrubiarte. Analysis and interpretation of data: Florence Dufreneix, Marie-Hélène Perruchot and Frédéric Dessauge. Drafting of manuscript: Marie-Hélène Perruchot and Frédéric Dessauge. Critical revision: Vanessa Lollivier, Eric Chanat and Laurence Finot. All authors will disclose any commercial associations that might create a conflict of interest in connection with this manuscript. 


\section{LITTERATURE}

1. Boutinaud M, J Guinard-Flament and H Jammes. (2004). The number and activity of mammary epithelial cells, determining factors for milk production. Reproduction Nutrition Development 44 499-508.

2. Chiche A, M Moumen, V Petit, J Jonkers, D Medina, MA Deugnier, MM Faraldo and MA Glukhova. (2013). Somatic loss of p53 leads to stem/progenitor cell amplification in both mammary epithelial compartments, basal and luminal. Stem Cells 31:1857-67.

3. Inman JL, C Robertson, JD Mott and MJ Bissell. (2015). Mammary gland development: cell fate specification, stem cells and the microenvironment. Development 142:1028-42.

4. Stefanon B, M Colitti, G Gabai, CH Knight and CJ Wilde. (2002). Mammary apoptosis and lactation persistency in dairy animals. Journal of Dairy Research 69:3752.

5. Visvader JE and J Stingl. (2014). Mammary stem cells and the differentiation hierarchy: current status and perspectives. Genes \& Development 28:1143-58.

6. Ellis SE and AV Capuco. (2002). Cell proliferation in bovine mammary epithelium: identification of the primary proliferative cell population. Tissue and Cell 34:155-163.

7. Borena BM, L Bussche, C Burvenich, L Duchateau and GR Van de Walle. (2013). Mammary stem cell research in veterinary science: an update. Stem cells and development 22:1743-51.

8. Deome KB, LJ Faulkin, Jr., HA Bern and PB Blair. (1959). Development of mammary tumors from hyperplastic alveolar nodules transplanted into gland-free mammary fat pads of female C3H mice. Cancer Research 19:515-20. 
9. Medina D and GH Smith. (1999). Chemical carcinogen-induced tumorigenesis in parous, involuted mouse mammary glands. Journal of the National Cancer Institute 91:967-9.

10. Ormerod EJ and PS Rudland. (1986). Regeneration of mammary glands in vivo from isolated mammary ducts. Journal of embryology and experimental morphology 96:229-43.

11. Baratta M, MG Volpe, D Nucera, G Gabai, N Guzzo, M Faustini and E Martignani. (2015). Differential expression of living mammary epithelial cell subpopulations in milk during lactation in dairy cows. Journal of Dairy Science 98:6897-904.

12. Martignani E, P Eirew, P Accornero, CJ Eaves and M Baratta. (2010). Human milk protein production in xenografts of genetically engineered bovine mammary epithelial stem cells. PloS one 5:e13372.

13. Shackleton M, F Vaillant, KJ Simpson, J Stingl, GK Smyth, ML Asselin-Labat, L Wu, GJ Lindeman and JE Visvader. (2006). Generation of a functional mammary gland from a single stem cell. Nature 439:84-8.

14. Stingl J, P Eirew, I Ricketson, M Shackleton, F Vaillant, D Choi, HI Li and CJ Eaves. (2006). Purification and unique properties of mammary epithelial stem cells. Nature 439:993-7.

15. Rauner G and I Barash. (2012). Cell hierarchy and lineage commitment in the bovine mammary gland. PloS one 7:e30113.

16. Ghebeh H, GM Sleiman, PS Manogaran, A Al-Mazrou, E Barhoush, FH Al-Mohanna, A Tulbah, K Al-Faqeeh and CN Adra. (2013). Profiling of normal and malignant breast tissue show CD44high/CD24low phenotype as a predominant stem/progenitor marker when used in combination with Ep-CAM/CD49f markers. BMC Cancer 13:289. 
17. Shehata M, A Teschendorff, G Sharp, N Novcic, IA Russell, S Avril, M Prater, P Eirew, C Caldas, CJ Watson and J Stingl. (2012). Phenotypic and functional characterisation of the luminal cell hierarchy of the mammary gland. Breast cancer research : BCR 14:R134.

18. Prpar S, E Martignani, P Dovc and M Baratta. (2012). Identification of goat mammary stem/progenitor cells. Biology of Reproduction 86:117.

19. Dey D, M Saxena, AN Paranjape, V Krishnan, R Giraddi, MV Kumar, G Mukherjee and A Rangarajan. (2009). Phenotypic and functional characterization of human mammary stem/progenitor cells in long term culture. PloS one 4:e5329.

20. Dontu G, WM Abdallah, JM Foley, KW Jackson, MF Clarke, MJ Kawamura and MS Wicha. (2003). In vitro propagation and transcriptional profiling of human mammary stem/progenitor cells. Genes \& Development 17:1253-70.

21. Villadsen R, AJ Fridriksdottir, L Ronnov-Jessen, T Gudjonsson, F Rank, MA LaBarge, MJ Bissell and OW Petersen. (2007). Evidence for a stem cell hierarchy in the adult human breast. The Journal of cell biology 177:87-101.

22. Maguer-Satta V, R Besancon and E Bachelard-Cascales. (2011). Concise review: neutral endopeptidase (CD10): a multifaceted environment actor in stem cells, physiological mechanisms, and cancer. Stem Cells 29:389-96.

23. Moritani S, R Kushima, H Sugihara, M Bamba, TK Kobayashi and T Hattori. (2002). Availability of CD10 immunohistochemistry as a marker of breast myoepithelial cells on paraffin sections. Modern pathology : an official journal of the United States and Canadian Academy of Pathology, Inc 15:397-405.

24. Safayi S, N Korn, A Bertram, RM Akers, AV Capuco, SL Pratt and S Ellis. (2012). Myoepithelial cell differentiation markers in prepubertal bovine mammary gland: effect of ovariectomy. Journal of Dairy Science 95:2965-76. 
25. Farr VC, K Stelwagen, LR Cate, AJ Molenaar, TB McFadden and SR Davis. (1996). An improved method for the routine biopsy of bovine mammary tissue. Journal of Dairy Science 79 543-549.

26. Livak KJ and TD Schmittgen. (2001). Analysis of relative gene expression data using real-time quantitative PCR and the 2(-Delta Delta C(T)) Method. Methods 25:402-8.

27. Moll R, M Divo and L Langbein. (2008). The human keratins: biology and pathology. Histochemistry and cell biology 129:705-33.

28. Ontsouka EC, JS Bertschi, X Huang, M Luthi, S Muller and C Albrecht. (2016). Can widely used cell type markers predict the suitability of immortalized or primary mammary epithelial cell models? Biological research 49:1.

29. Stingl J, A Raouf, P Eirew and CJ Eaves. (2006). Deciphering the mammary epithelial cell hierarchy. Cell cycle 5:1519-22.

30. Koukoulis GK, I Virtanen, M Korhonen, L Laitinen, V Quaranta and VE Gould. (1991). Immunohistochemical localization of integrins in the normal, hyperplastic, and neoplastic breast. Correlations with their functions as receptors and cell adhesion molecules. The American journal of pathology 139:787-99.

31. Stingl J, CJ Eaves, I Zandieh and JT Emerman. (2001). Characterization of bipotent mammary epithelial progenitor cells in normal adult human breast tissue. Breast Cancer Research and Treatment 67:93-109.

32. Keller PJ, AF Lin, LM Arendt, I Klebba, AD Jones, JA Rudnick, TA DiMeo, H Gilmore, DM Jefferson, RA Graham, SP Naber, S Schnitt and C Kuperwasser. (2010). Mapping the cellular and molecular heterogeneity of normal and malignant breast tissues and cultured cell lines. Breast cancer research : BCR 12:R87.

33. Smith GH and D Medina. (2008). Re-evaluation of mammary stem cell biology based on in vivo transplantation. Breast cancer research : BCR 10:203. 
34. Capuco AV, D Wood, R Baldwin, K McLeod and M Paape. (2001). Mammary cell number, proliferation, and apoptosis during a bovine lactation: relation to milk production and effect of bST. Journal of Dairy Science 84:2177

$-2187$.

35. Adriance MC, JL Inman, OW Petersen and MJ Bissell. (2005). Myoepithelial cells: good fences make good neighbors. Breast cancer research : BCR 7:190-7.

36. Clarke C, J Titley, S Davies and MJ O'Hare. (1994). An immunomagnetic separation method using superparamagnetic (MACS) beads for large-scale purification of human mammary luminal and myoepithelial cells. Epithelial cell biology 3:38-46.

37. Sarrio D, CK Franklin, A Mackay, JS Reis-Filho and CM Isacke. (2012). Epithelial and mesenchymal subpopulations within normal basal breast cell lines exhibit distinct stem cell/progenitor properties. Stem Cells 30:292-303.

38. Demontis F, R Piccirillo, AL Goldberg and N Perrimon. (2013). Mechanisms of skeletal muscle aging: insights from Drosophila and mammalian models. Disease models \& mechanisms 6:1339-52.

39. Sleeman KE, H Kendrick, D Robertson, CM Isacke, A Ashworth and MJ Smalley. (2007). Dissociation of estrogen receptor expression and in vivo stem cell activity in the mammary gland. The Journal of cell biology 176:19-26.

40. Lim E, D Wu, B Pal, T Bouras, ML Asselin-Labat, F Vaillant, H Yagita, GJ Lindeman, GK Smyth and JE Visvader. (2010). Transcriptome analyses of mouse and human mammary cell subpopulations reveal multiple conserved genes and pathways. Breast cancer research : BCR 12:R21. 


\section{FIGURE LEGENDS}

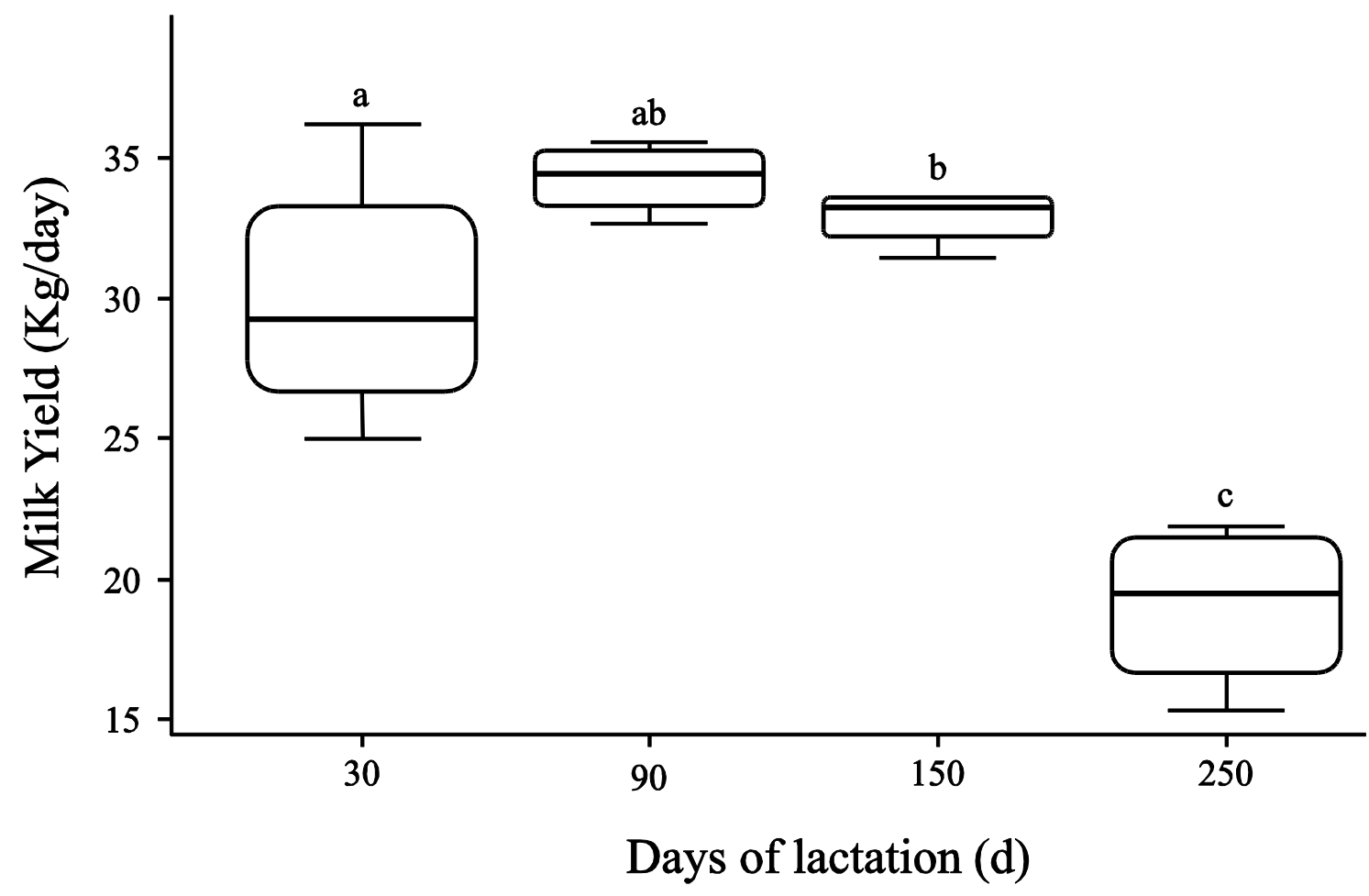

Perruchot et al., 2016

Figure 1

Figure 1: Representative box plots of milk yield during the lactation cycle. Each box plot represents the mean (five dairy cows) of daily milk production $(\mathrm{kg} /$ day) prior to mammary gland biopsy at the indicated time point. The letters above the boxplots indicate statistically significant $(p<0.05)$ differences between each value and the value at each of the other three time points. 

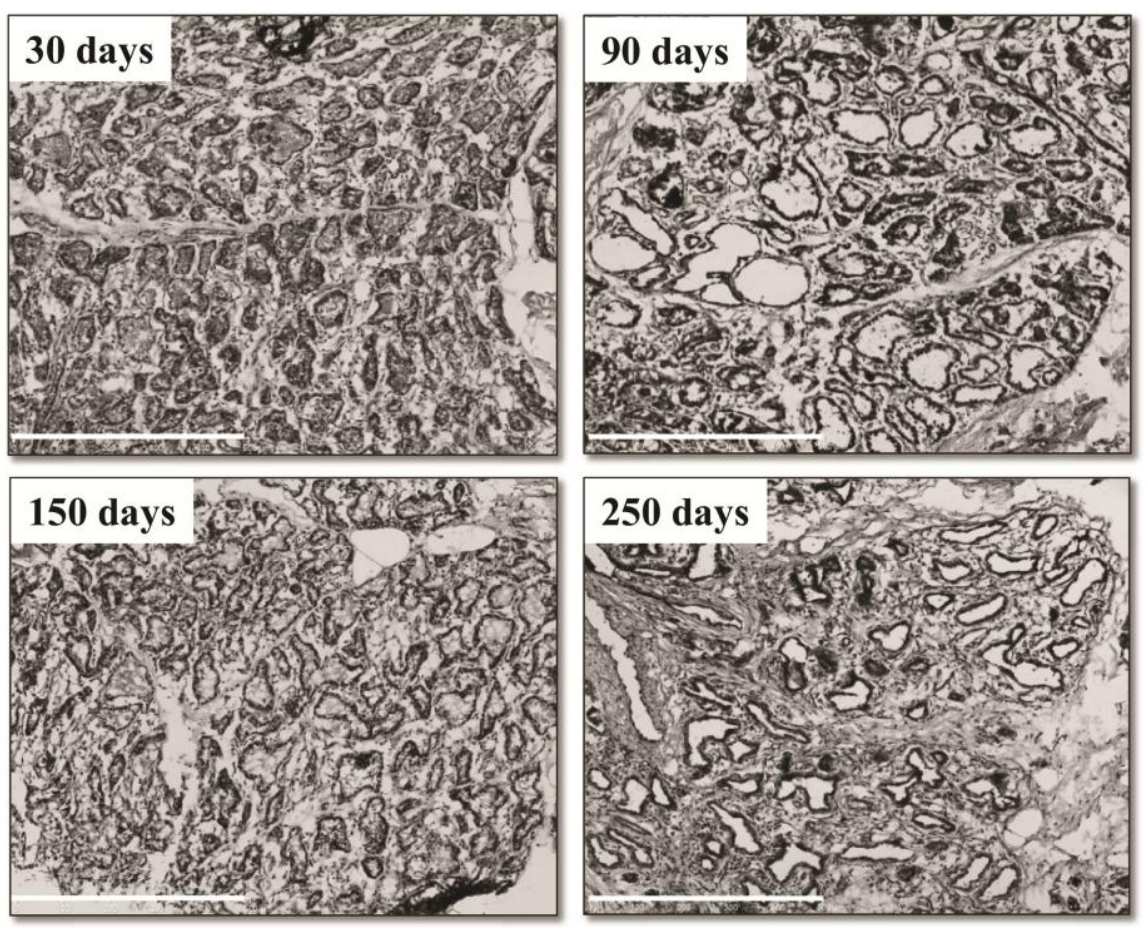

Perruchot et al., 2016

Figure 2

Figure 2: Organization of the mammary gland secretory tissue throughout lactation.

Mammary tissue was collected by biopsy at 30, 90, 150 and 250 days of lactation and processed for hematoxylin/eosin histological staining. The stained tissue sections were scanned using a NanoZoomer (Hamamatsu). Scale bar $=500 \mu \mathrm{m}$. 


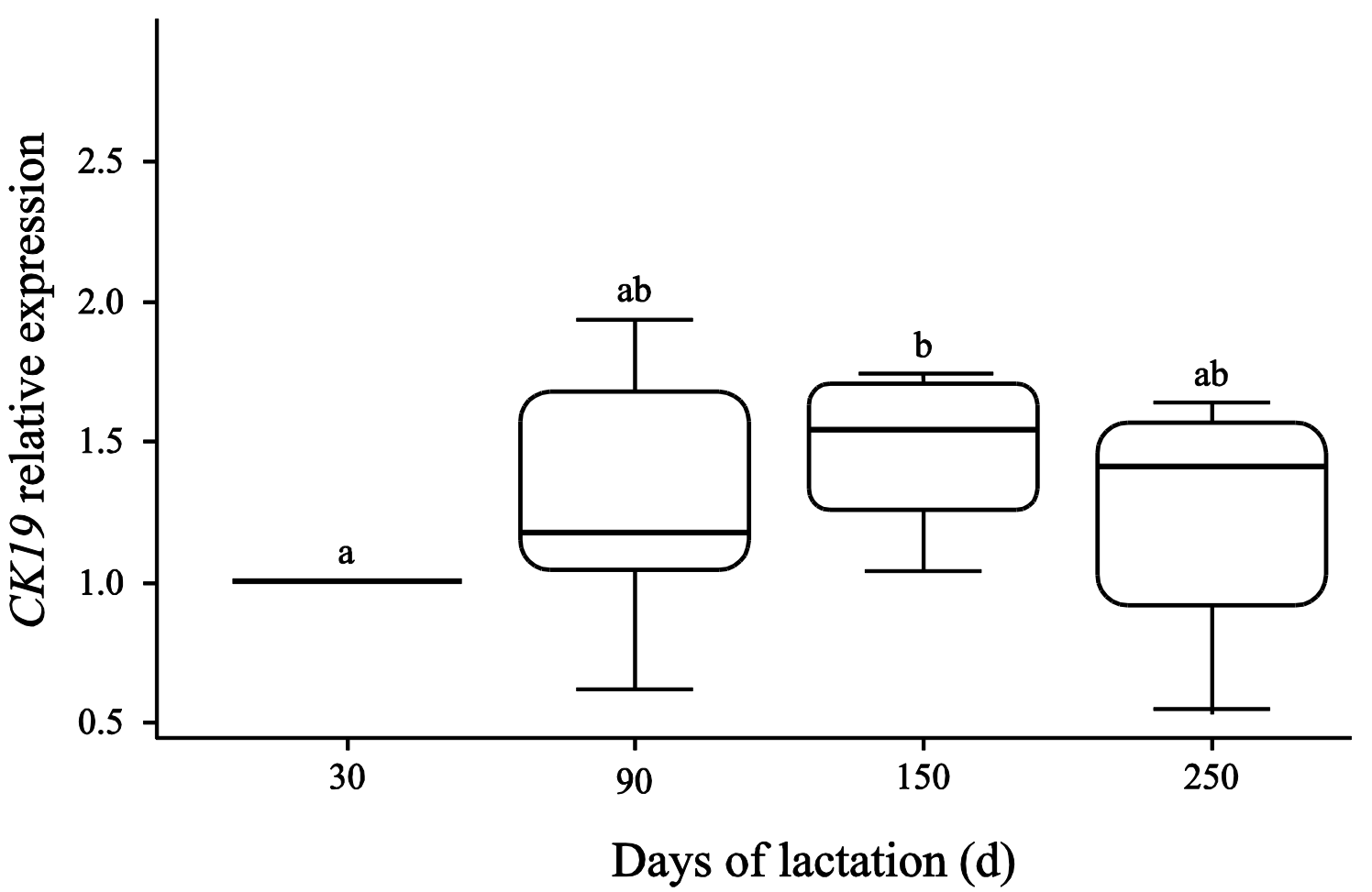

Perruchot et al., 2016

Figure 3

Figure 3: Representative box plots of relative $C K 19$ gene expression throughout lactation. Each box plot represents the mean (five dairy cows) of $C K 19$ expression at the indicated time point prior to mammary biopsy (RPLP0 was used as the reference gene). Results at days 90, 150 and 250 are expressed as percent of the tissue content at day 30. Different letters above the box plots indicate statistically significant $(p<0.05)$ differences between each value and the value at each of the other three time points. 
Page 33 of 49

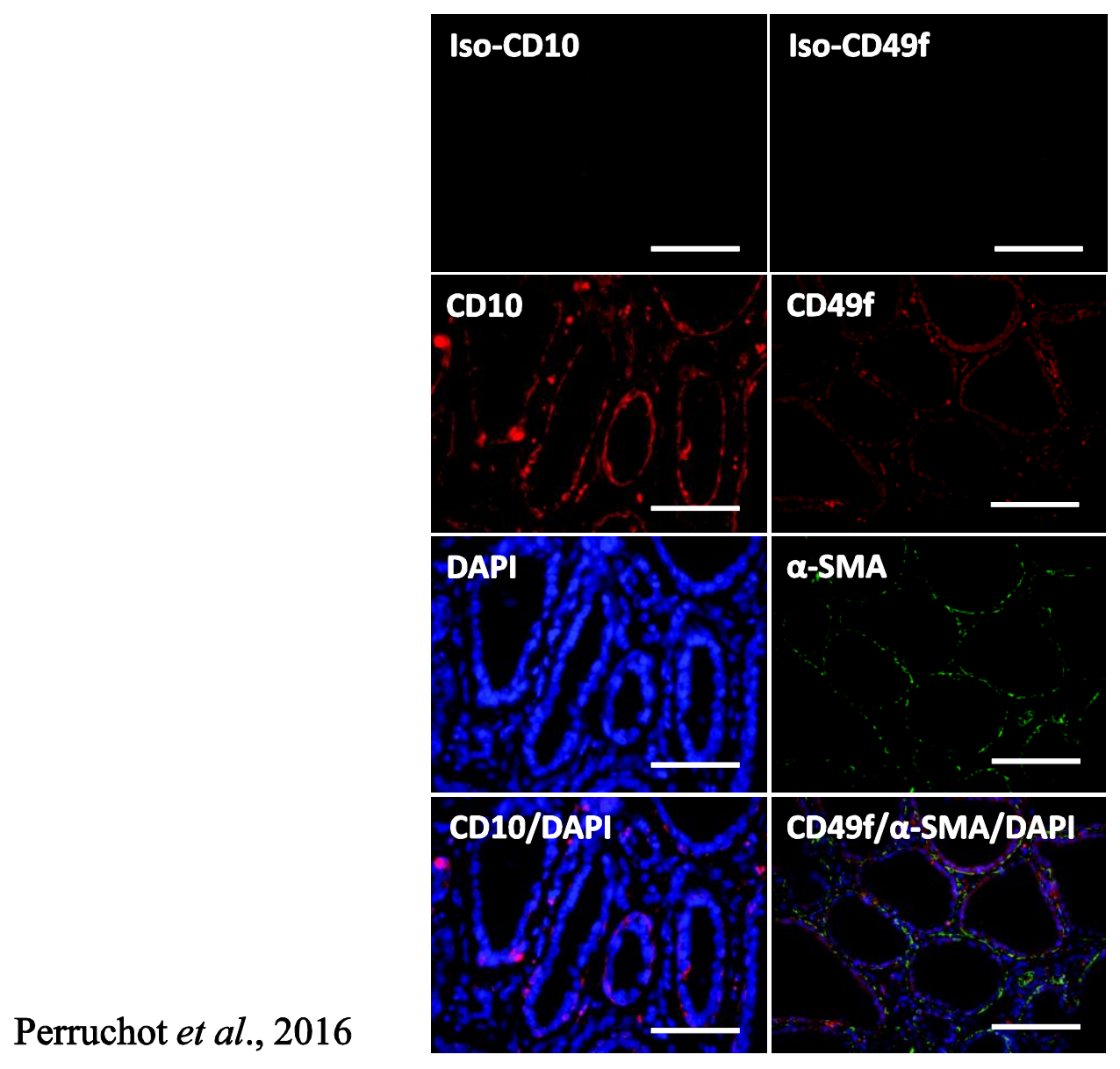

Figure 4A 


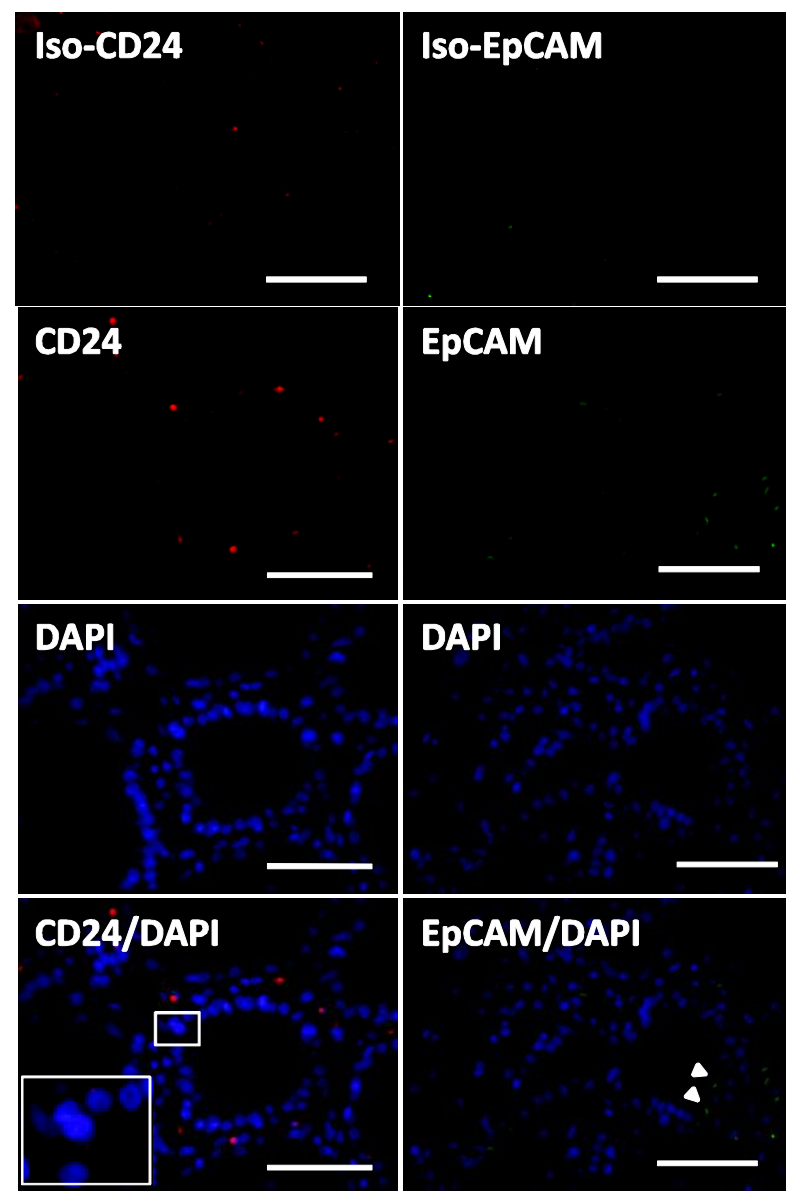

\section{Figure 4B}

Figure 4: In situ localization of cell-surface markers in lactating mammary gland tissue. (A)

The left panels show the staining of myoepithelial cells using the iso-CD10 and CD10 antibodies. Nuclei were counterstained with DAPI. The right panels show basal part of the

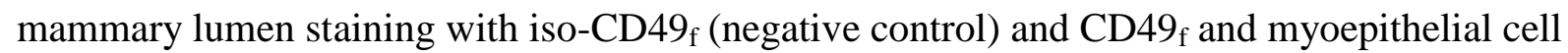
staining with $\alpha$-SMA. (B) The left panels show the staining of some of the luminal cells using the anti-CD24 antibody compared with the negative control iso-CD24. The right panels show the negative control iso-EpCAM and the apical staining (white arrows) in some of the luminal MEC within the mammary acini using anti-EpCAM antibody. Nuclei were counterstained with DAPI. Scale bars $=50 \mu \mathrm{m}$. 
(3)

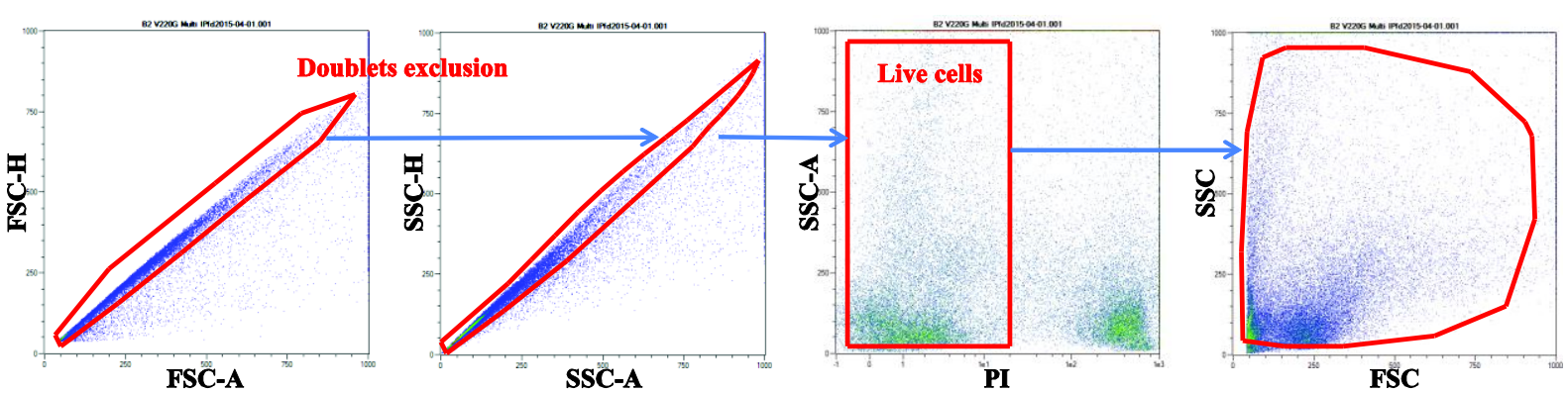

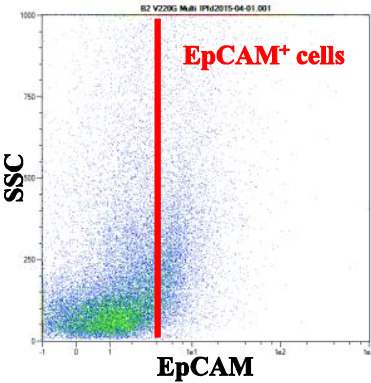
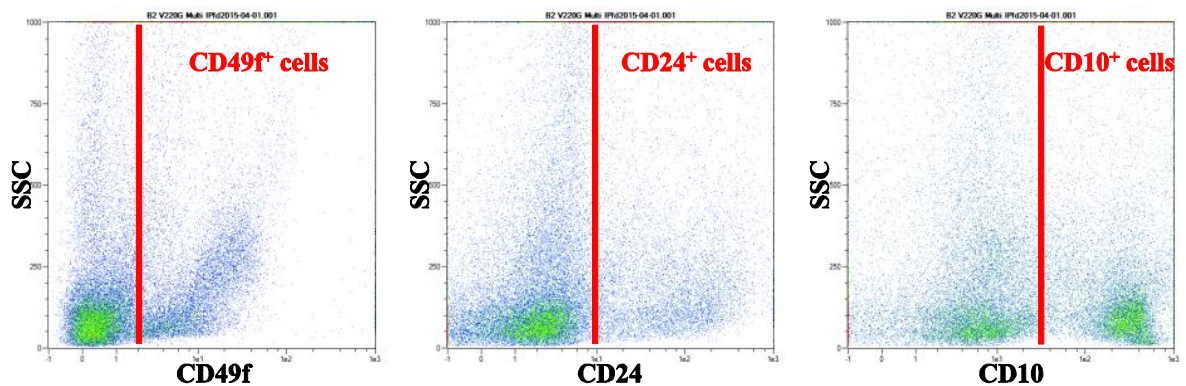

Perruchot et al., 2016
Figure 5A 

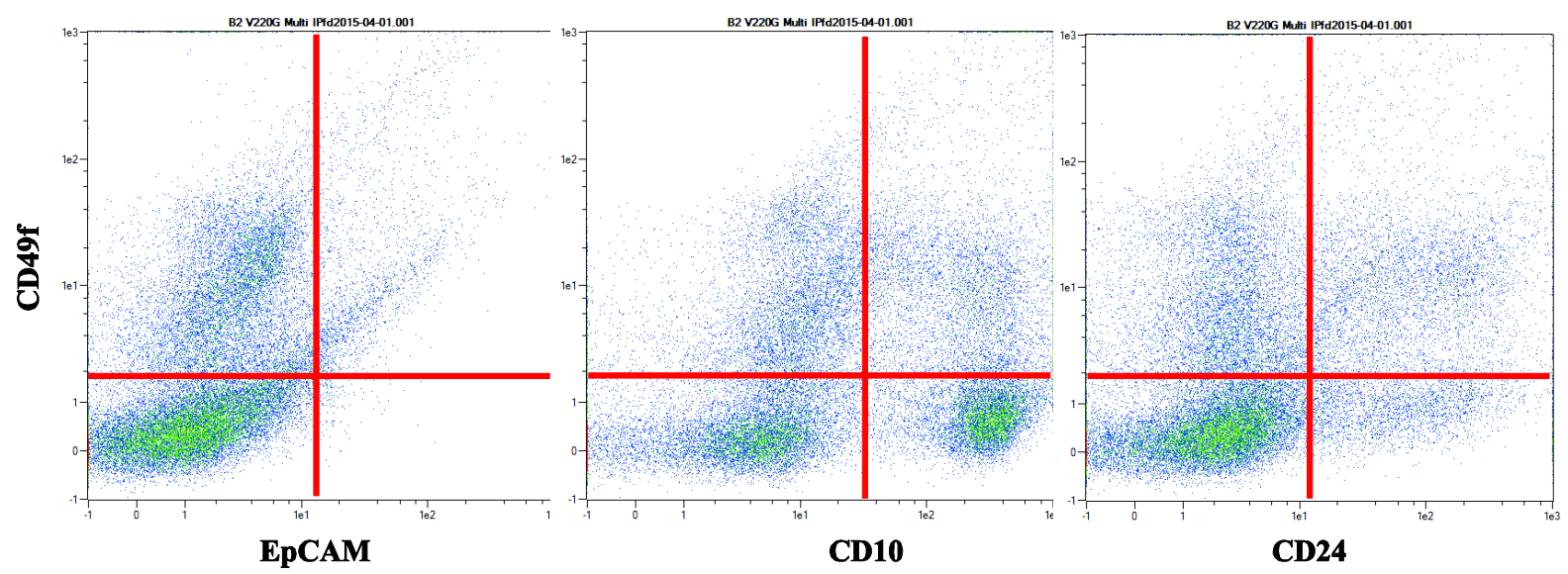

Perruchot et al., 2016

Figure 5B

Figure 5: Gating strategy used to analyze the stained cell populations by flow cytometry. (A) Gating strategy to set up the analysis of single living cells. Doublet exclusion using FSC-H/A and SSC-H/A parameters was performed. Propidium iodide allowed discrimination between living cells and dead cells. Each single staining with anti-CD49, , -CD10, -CD24 and -EpCAM antibodies was analyzed in living cells. (B) Illustration of the gating strategy used to analyze the multi-stained populations. Gated CD49f-positive cells were selected and then coimmunostained populations were analyzed: CD49 ${ }_{\mathrm{f}}$ and EpCAM, CD49 $9_{\mathrm{f}}$ and CD10, CD49 $9_{\mathrm{f}}$ and CD24. 

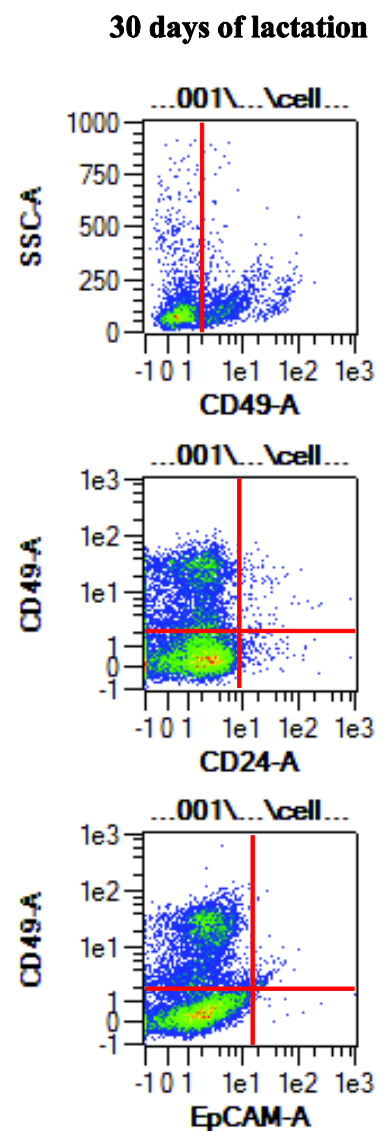

Perruchot et al., 2016
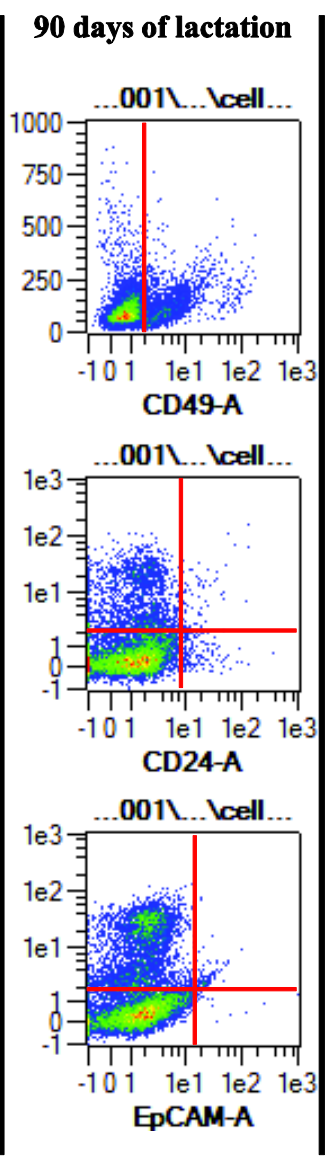

150 days of lactation

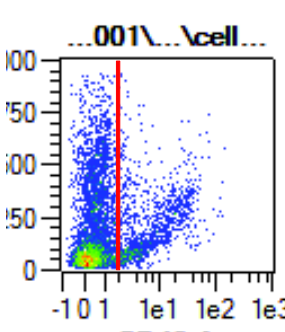

CD49-A
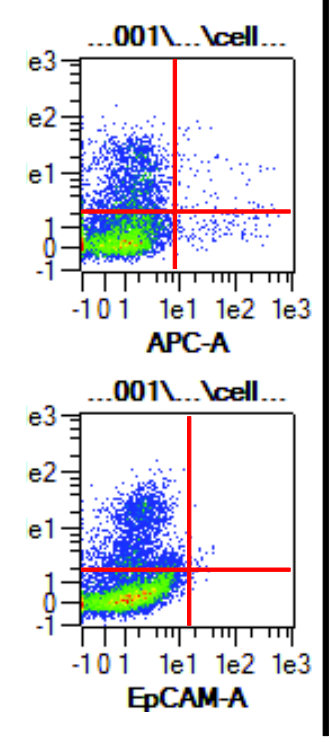

250 days of lactation
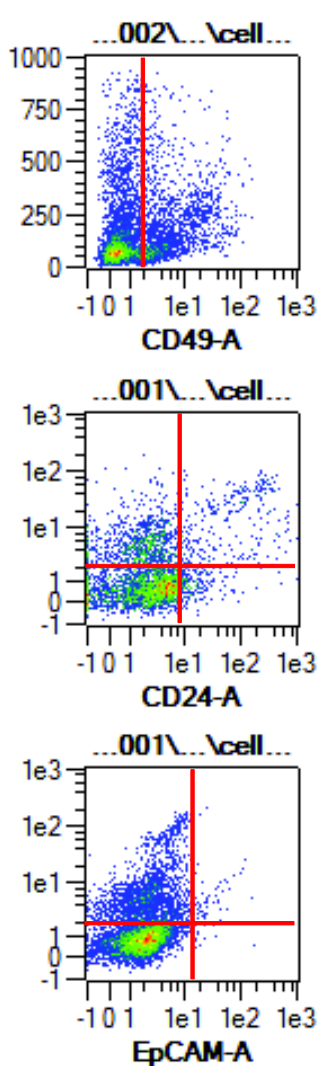

Figure 6

Figure 6: Evolution of main MEC populations over the lactation. Flow cytometry dot-plots depicting the main populations at 30 days, 90 days, 150 days and 250 days of lactation. Upper panels highlighted CD49 $9_{\mathrm{f}}$-positive cells, middle panels: CD49/ $/ \mathrm{CD} 24$ populations and lower panels: CD49f/EpCAM populations. 


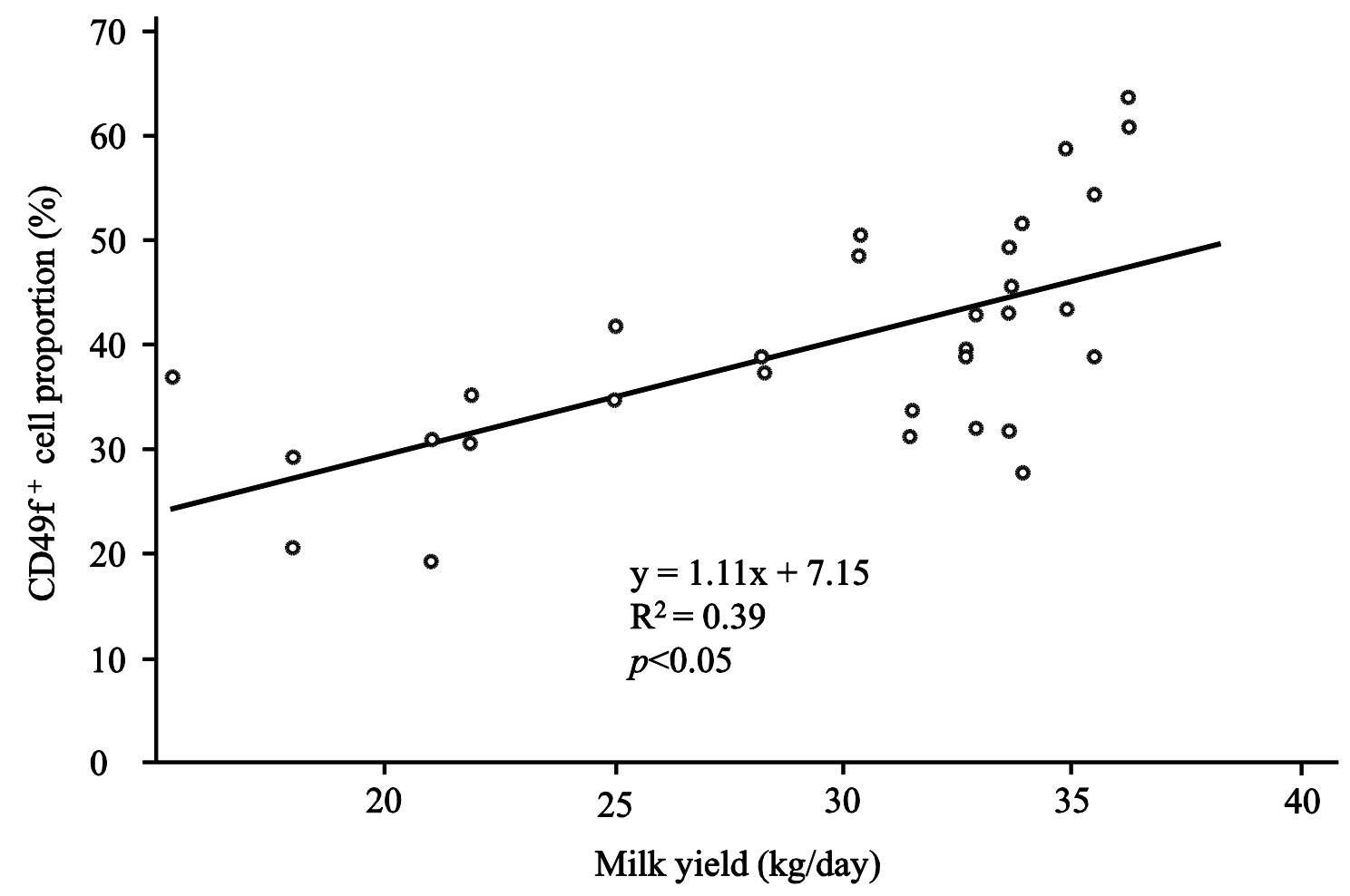

Perruchot et al., 2016

Figure 7A 

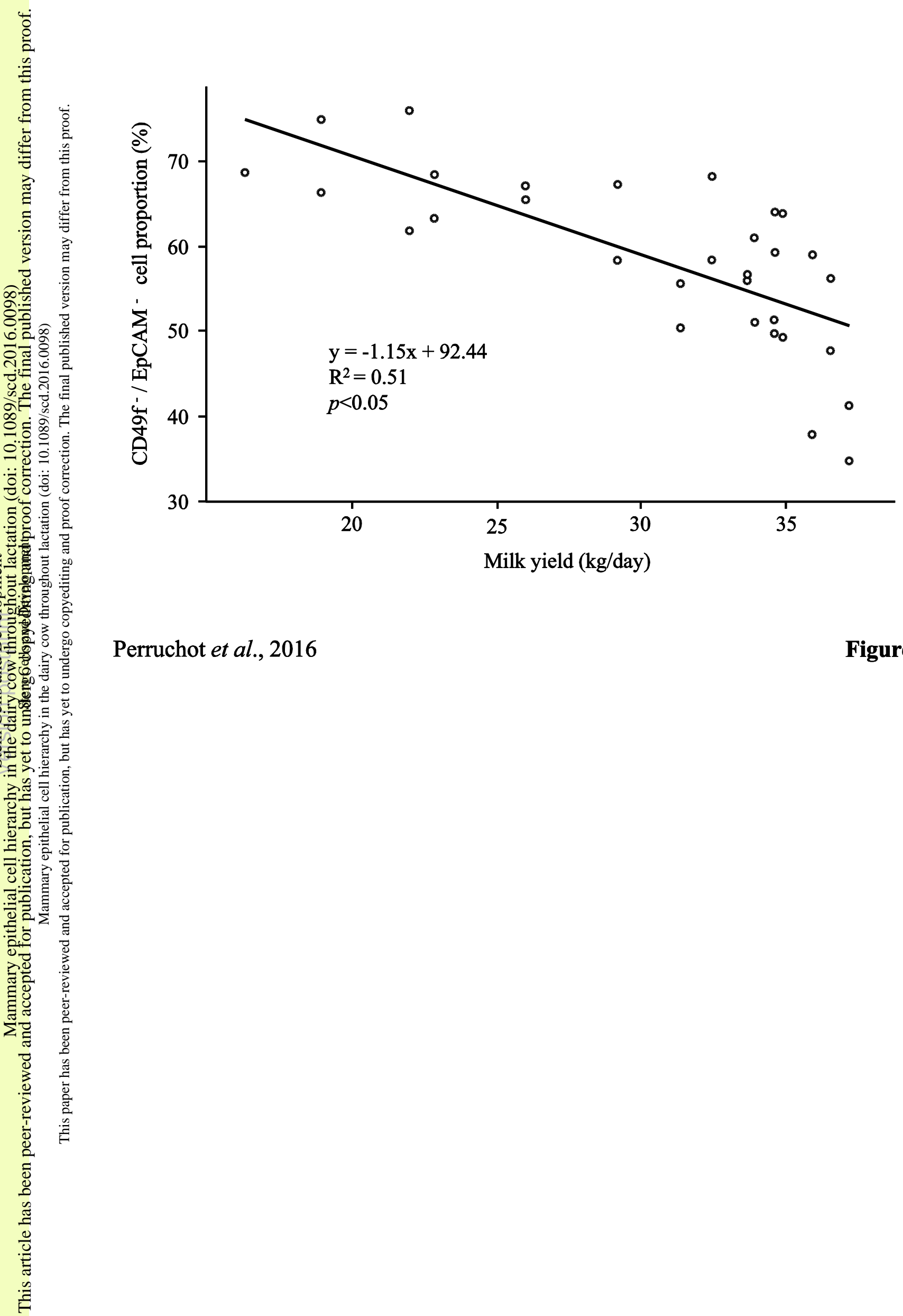

Perruchot et al., 2016

Figure 7B 


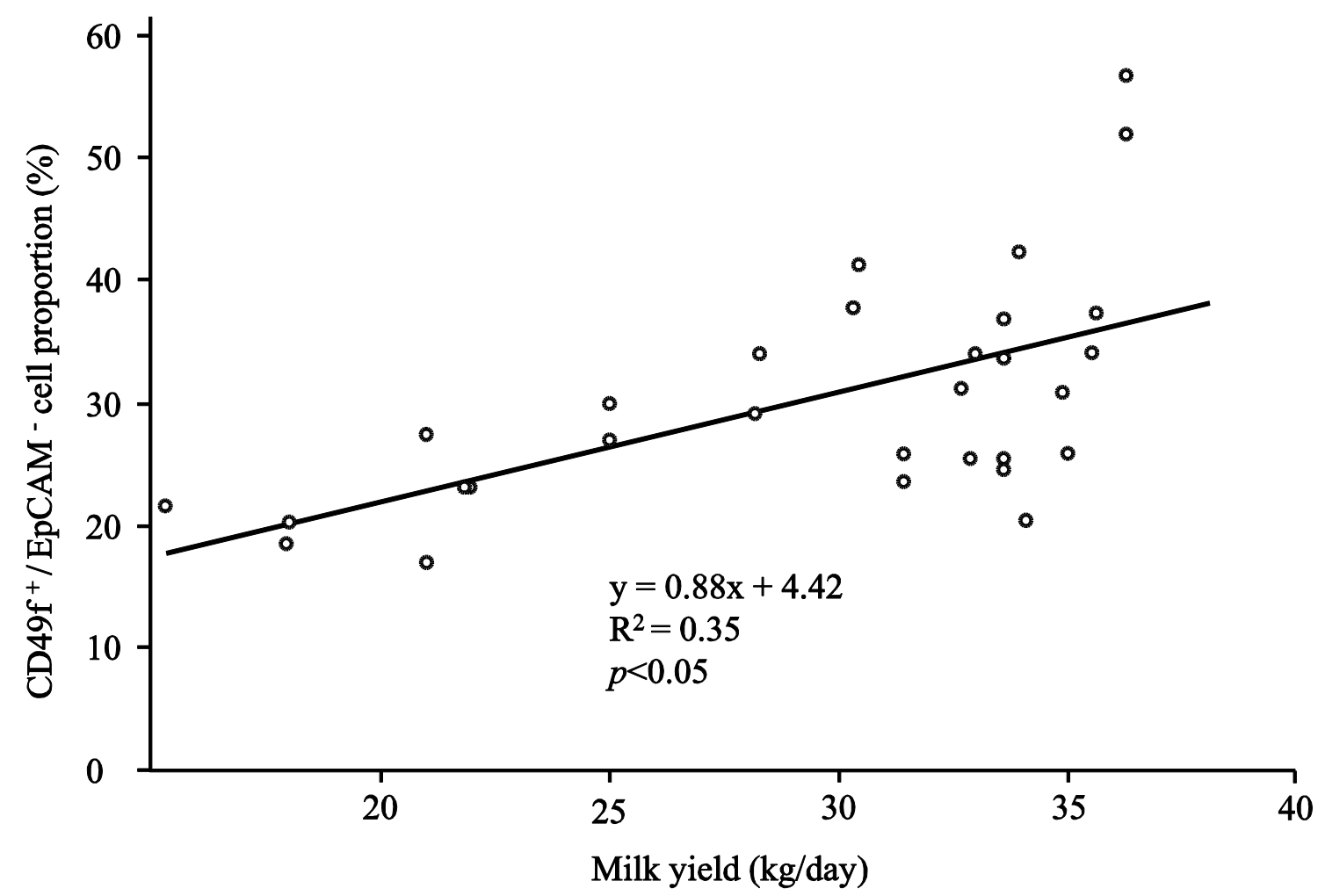

Perruchot et al., 2016

Figure 7C

Figure 7: Analysis of the correlation between the proportions of various cell populations and milk yield. (A) Correlation between the proportion of CD49 $9_{\mathrm{f}}$-positive cells and milk yield $\left(\mathrm{MY}, \mathrm{R}^{2}=0.39, p<0.05\right)$. (B) Correlation between the proportion of CD49- ${ }_{\mathrm{f}}^{-} / \mathrm{EpCAM}^{-}$cells and MY $\left(\mathrm{R}^{2}=0.51, p<0.05\right)$. (C) Correlation between the proportion of $\mathrm{CD}_{4} 9_{\mathrm{f}}^{+} / \mathrm{EpCAM}^{-}$ cells and MY $\left(\mathrm{R}^{2}=0.35, p<0.05\right)$. 


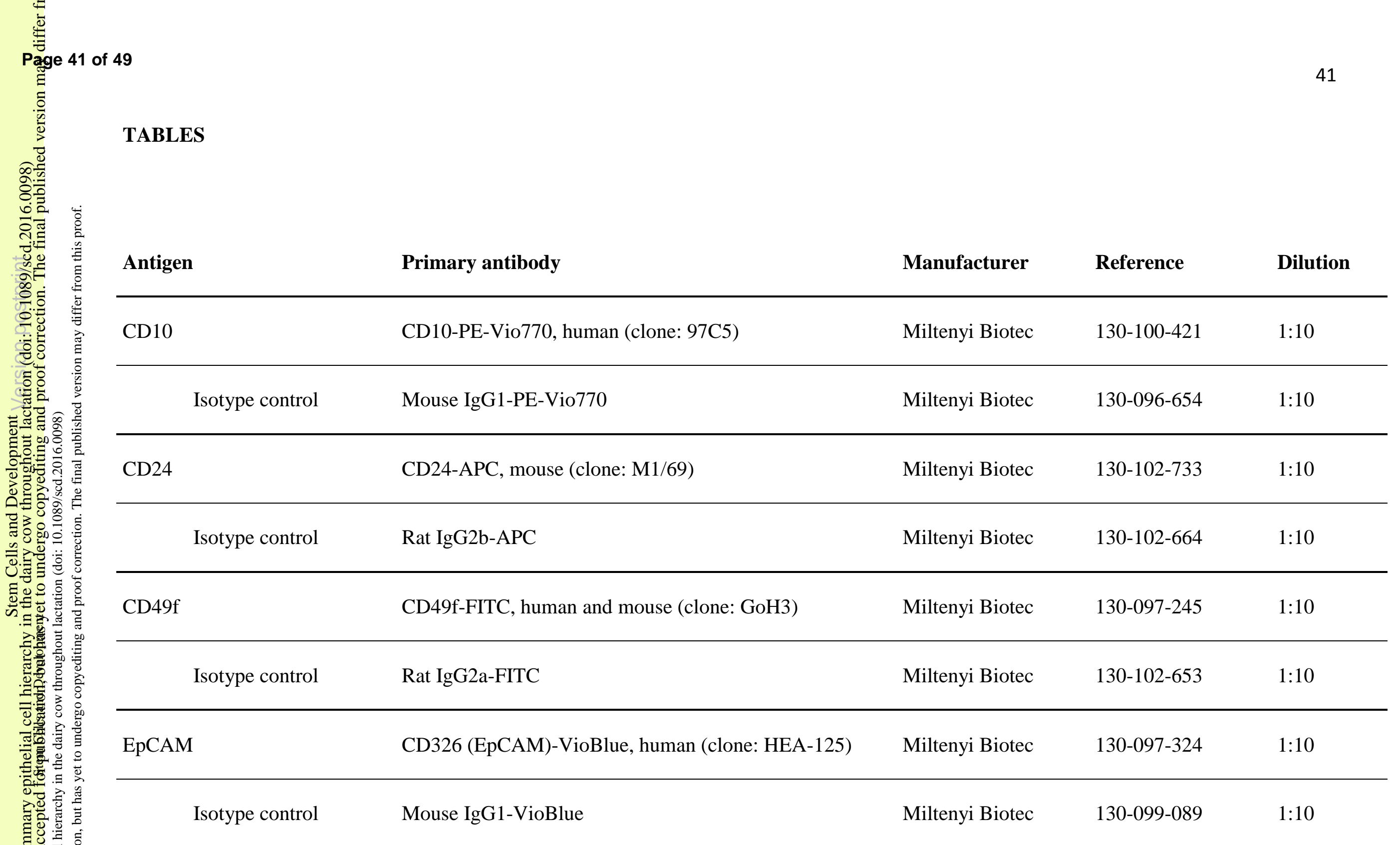




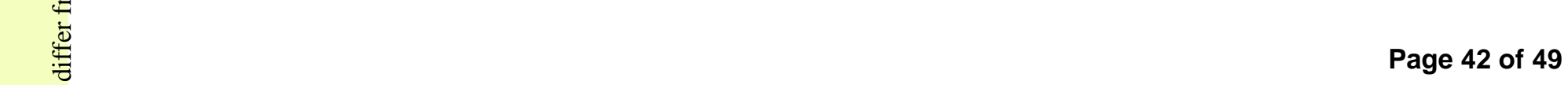

Table 1: List of antibodies used in flow cytometry analysis and immunohistology. 


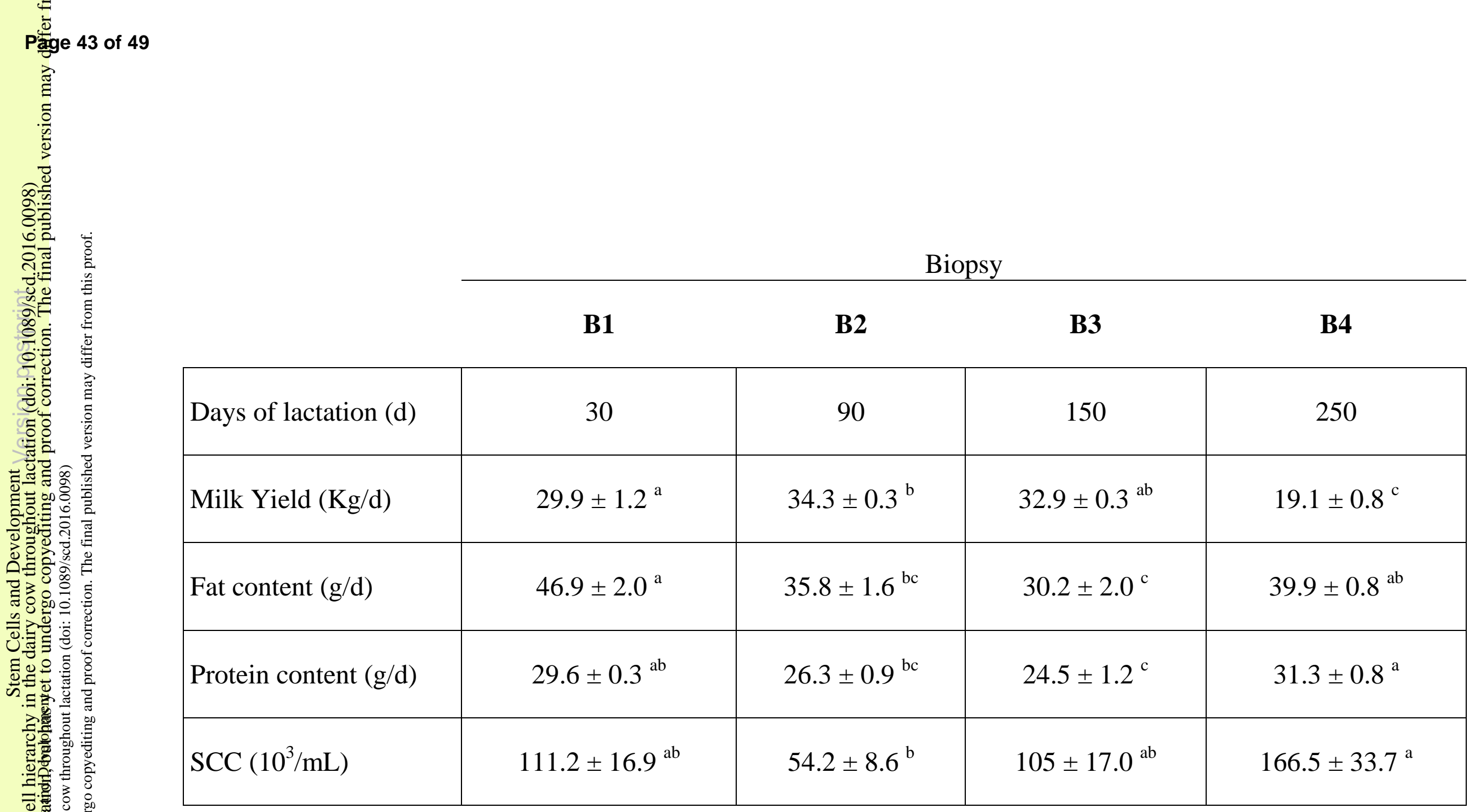




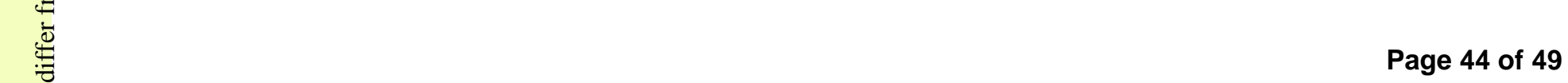

Table 2: Milk yield, fat and protein contents and somatic cell count during lactation. The milk of five primiparous lactating cows was collected throughout lactation. The MY was recorded daily over 52 weeks. Milk samples were collected weekly for somatic cell counting (SCC) and to determine the milk fat and protein composition. The data are expressed as the mean values ( \pm SEM) at 30 (biopsy 1: B1), 90 (B2), 150 (B3) and 250 (B4) days of lactation. Different letters indicate statistically significant $(p<0.05)$ differences between each value and the value at each of the other three time points. 


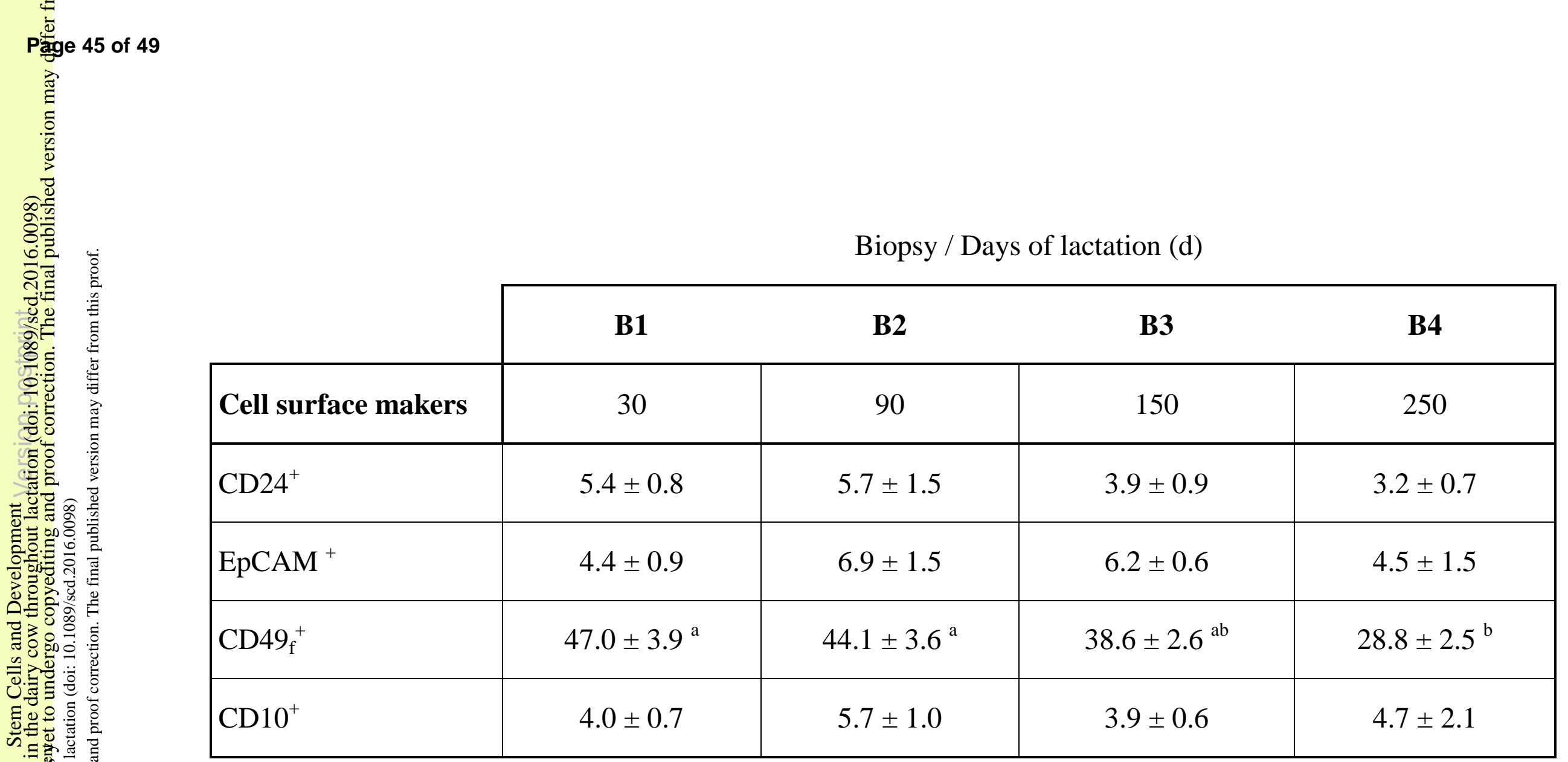

Perruchot et al., 2016

Table 3

Table 3: Flow cytometry analysis of isolated cells dissociated from mammary biopsies using single staining. Mammary biopsies were collected at 30 (biopsy 1: B1), 90 (B2), 150 (B3) and 250 (B4) days of lactation. After tissue digestion and cell dissociation, single cell suspensions were 


\section{离 $\quad$ Page 46 of 49}

phenotyped using anti-CD24, -EpCAM, -CD10 and -CD49f antibodies. Each data point corresponds to the mean ( \pm SEM) of fluorescence for each single staining. Different letters indicate statistically significant $(p<0.05)$ differences between each value and the values at each of the other three time points. 


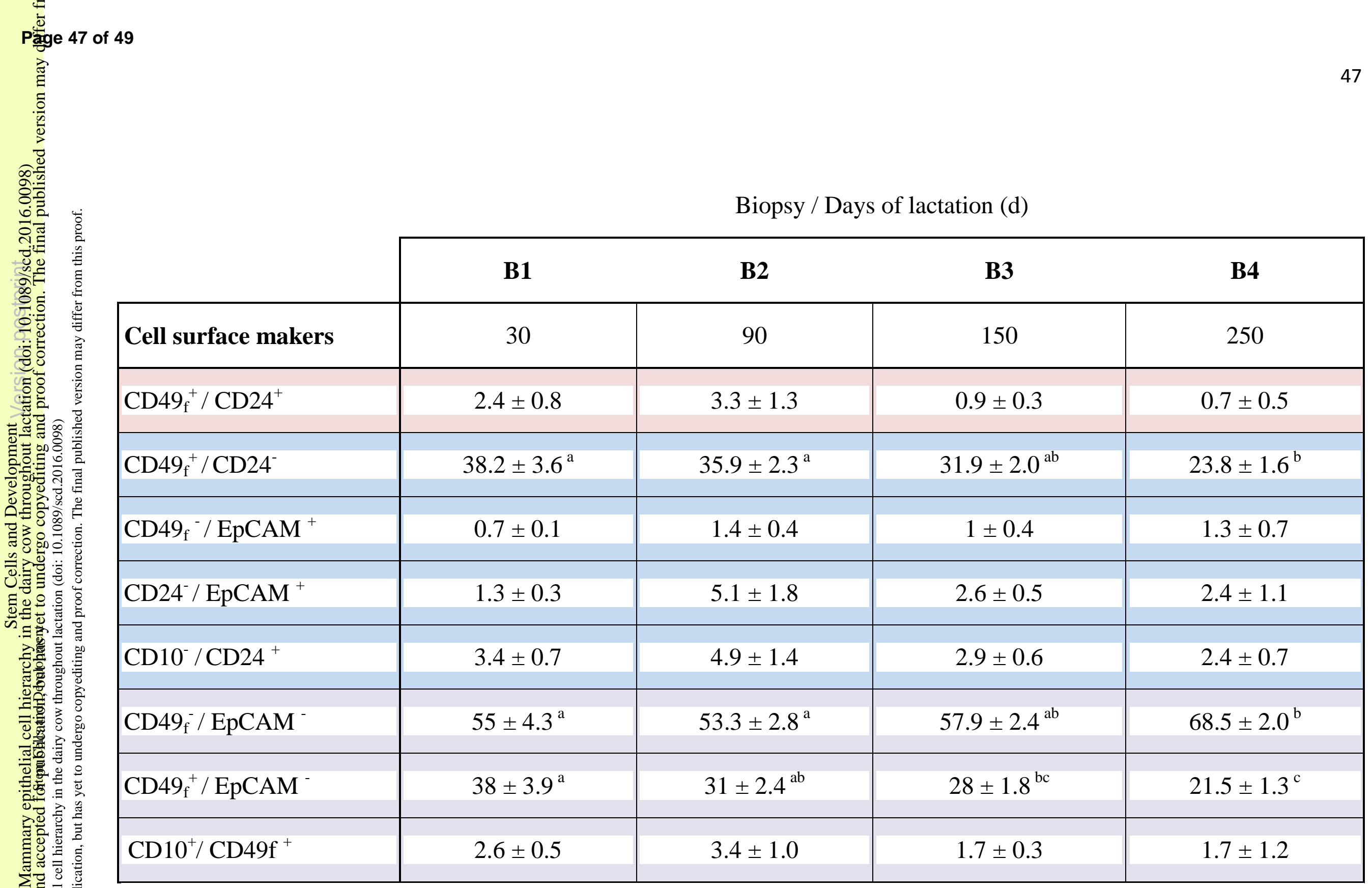




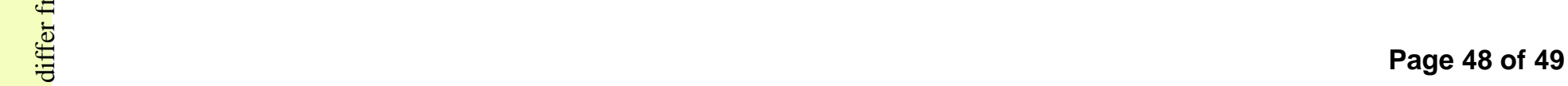

Perruchot et al., 2016

Table 4

Table 4: Cell hierarchy and lineages in the bovine mammary gland throughout a lactation period. Mammary biopsies were collected at 30 (biopsy 1: B1), 90 (B2), 150 (B3) and 250 (B4) days of lactation. After tissue digestion, cell dissociation and single cell isolation, the proportion of each cell type was determined at each stage of lactation according to the expression of cell-surface markers. The proportions of double-stained cell populations, using EpCAM, CD49, CD24 and CD10 markers, are presented as the mean of fluorescence ( \pm SEM). Different letters indicate statistically significant $(p<0.05)$ differences between each value and the values at each of the other three time points. 
Page 49 of 49

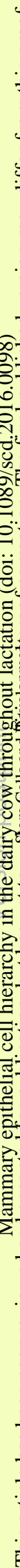

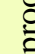

告

ฐ̊ํํ

氖

$>$

ป

क्र

o-

○े

중잉

ठु है

ने

of

웡으.

훙

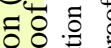

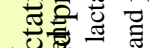

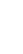

